\title{
Catalytic Asymmetric Total Syntheses of Quinine and Quinidine
}

Izzat T. Raheem, Steven N. Goodman, Eric N. Jacobsen*

Department of Chemistry and Chemical Biology, Harvard University; Cambridge, MA 02138

\section{Supporting Information}

General Procedures. All reactions were performed in oven-dried or flame-dried round bottomed flasks. The flasks were fitted with rubber septa and reactions were conducted under a positive pressure of nitrogen, unless otherwise noted. Stainless steel syringes or cannulae were used to transfer air- and moisture-sensitive liquids. Flash chromatography was performed using silica gel 60 (230-400 mesh) from EM Science.

Materials. Commercial reagents were purchased from Sigma Aldrich, Alfa Aesar, EM Science, and Igo and used as received. All solvents were used after being freshly distilled, unless otherwise noted.

Instrumentation. Proton nuclear magnetic resonance $\left({ }^{1} \mathrm{H}\right.$ NMR) spectra and carbon nuclear magnetic resonance $\left({ }^{13} \mathrm{C}\right.$ NMR) spectra were recorded on a Varian Mercury-400 $(400 \mathrm{MHz})$ or Inova-500 (500 MHz) NMR spectrometer. Chemical shifts for protons are reported in parts per million downfield from tetramethylsilane and are referenced to residual NMR solvent peak $\left(\mathrm{CHCl}_{3}: \delta 7.26,\left(\mathrm{CD}_{3}\right)_{2} \mathrm{SO}: \delta\right.$ 2.49). Chemical shifts for carbon are reported in parts per million downfield from tetramethylsilane and are referenced to the carbon resonances of the solvent $\left(\mathrm{CDCl}_{3}: \delta 77.0\right)$. Data are represented as follows: chemical shift, multiplicity $(\mathrm{br}=$ broad, $\mathrm{s}=$ singlet, $\mathrm{d}=$ doublet, $\mathrm{t}=$ triplet, $\mathrm{q}=$ quartet, $\mathrm{m}=$ multiplet), coupling constants in Hertz $(\mathrm{Hz})$, and integration.

Infrared (IR) spectra were obtained using a Mattson Galaxy Series FTIR 3000 spectrophotometer referenced to a polystyrene standard. Data are represented as follows: frequency of absorption $\left(\mathrm{cm}^{-1}\right)$, intensity of absorption $(\mathrm{s}=$ strong, $\mathrm{m}=$ medium, $\mathrm{w}=$ weak).

Achiral gas chromatography (GC) analyses were performed on Hewlett-Packard 5890 Series II instruments equipped with FID detectors, a Hewlett-Packard 7673 Automatic Liquid Sampler and an HP-5 capillary column ( $30 \mathrm{~m}$ x $0.32 \mathrm{~mm}$ i.d. x $0.25 \mathrm{~m}$ film) using hydrogen as a carrier gas.

Microwave reactions were carried out in a Personal Chemistry Smith Synthesizer ${ }^{\mathrm{TM}}$. Optical rotations were measured using a $2 \mathrm{~mL}$ cell with a $1 \mathrm{dm}$ path length on a Jasco DIP 370 digital polarimeter. Melting points were measured on a Mel-Temp apparatus, and are uncorrected. The mass spectroscopic data were obtained at the Harvard University mass spectrometry facility. Chiral HPLC analysis was performed on a Hewlett-Packard 1050 instrument.

Note on NMR Spectra. There is a prominent concentration effect in ${ }^{1} \mathrm{H}$ NMR and ${ }^{13} \mathrm{C}$ NMR spectra of the cinchona alkaloids (and of other quinoline-containing compounds bearing free hydroxyl groups), presumably due to significant intermolecular hydrogen 
bonding between the hydroxyls and either the quinoline or quinuclidine nitrogens. For this reason, proton spectra can vary significantly from run to run, and shifts have been observed to vary by as much as $0.35 \mathrm{ppm}\left({ }^{1} \mathrm{H}\right)$ and $2.00 \mathrm{ppm}\left({ }^{13} \mathrm{C}\right)$ in control experiments. For this reason, we have indicated the approximate concentrations of samples used in the indicated ${ }^{1} \mathrm{H}$ NMRs and ${ }^{13} \mathrm{C}$ NMRs.

Abbreviations used: EtOAc: ethyl acetate, THF: tetrahydrofuran, EtOH: ethnaol, $\mathrm{MeOH}$ : methanol, $\mathrm{Et}_{2} \mathrm{O}$ : diethyl ether, $t \mathrm{BuOH}$ : $t$-butyl alcohol, $\mathrm{CyH}$ : cyclohexane, IPA: isopropyl alcohol, $n$ BuLi: $n$-butyllithium, $\mathrm{KO} t \mathrm{Bu}$ : potassium $t$-butoxide, TBAF: tetrabutyl ammonium flouride, TPAP: tetrapropylammonium perruthenate, NMO: 4methylmorpholine $\mathrm{N}$-oxide, LDA: lithiumdiisopropyl amide, TEA: triethylamine, PPTS: pyridinium $p$-toluenesulfonate, $\mathrm{LN}_{2}$ : liquid nitrogen, $\mathrm{MS}$ : molecular seives, ee: enantiomeric excess, dr: diastereomeric ratio

(2-Benzoylamino-2-oxo-ethyl)-phosphonic acid diethyl ester $\left(\underline{7}^{1}{ }^{1}\right.$
Chloroacetyl chloride $(6.56 \mathrm{~mL}, 0.082 \mathrm{~mol})$ was added neat to
benzamide $(9.68 \mathrm{~g}, 0.080 \mathrm{~mol})$ in a flame-dried $100 \mathrm{~mL}$ roundbottom flask equipped with a stirbar and condenser, and the mixture was heated to $110^{\circ} \mathrm{C}$ under a balloon of nitrogen. Within $5 \mathrm{~min}$, the mixture became homogenous, the gradually became orange and solidified. After $30 \mathrm{~min}$, the mixture was cooled and volatiles removed under vacuum. $\mathrm{Et}_{2} \mathrm{O}(30 \mathrm{~mL})$ was added, the solid residue broken up, and the product collected by filtration to yield $\mathrm{N}$-(choloroacetyl) benzamide $(12.2 \mathrm{~g}, 77 \%$ yield), which was sufficiently pure for the next step in the reaction.

Crude N-(chloroacetyl) benzamide $(12.2 \mathrm{~g}, 0.062 \mathrm{~mol})$ was placed in a $25 \mathrm{~mL}$ round-bottom flask equipped with a stirbar and an air-cooled condenser. $\mathrm{P}(\mathrm{OEt})_{3}(26.3$ $\mathrm{mL}, 0.153 \mathrm{~mol}$ ) was added, and the mixture heated to $80^{\circ} \mathrm{C}$ under nitrogen, until the starting material was fully consumed $(24 \mathrm{~h})$. Upon cooling to room temperature, hexanes $(30 \mathrm{~mL})$ was added to the stirred mixture, and the clear top layer was decanted. This process was repeated $(3 \times 15 \mathrm{~mL}$ hexanes $)$ to remove excess $\mathrm{P}(\mathrm{OEt})_{3}$. The remaining residue was then recrystallized from $3: 1$ toluene/hexanes $(82 \mathrm{~mL})$ to afford the desired phosphanate imide $(14.2 \mathrm{~g}, 77 \%)$ as a slightly off-white solid. All spectral data matched literature values. ${ }^{1}$

3-(tert-Butyl-dimethyl-silanyloxy)-propionaldehyde $\left(\underline{8}^{2}\right.$ To a solution
of tert-butyl-dimethylchlorosilane $(10.6 \mathrm{~g}, 70 \mathrm{mmol})$ in $\mathrm{CH}_{2} \mathrm{Cl}_{2}(200 \mathrm{~mL})$
was added imidazole $(4.77 \mathrm{~g}, 70 \mathrm{mmol})$ at room temperature. To this reaction mixture was slowly added 3-buten-1-ol $(5.0 \mathrm{~g}, 69 \mathrm{mmol})$ dropwise. Upon completion of addition, the reaction was allowed to stir for $2 \mathrm{~h}$. The reaction mixture was diluted with $150 \mathrm{~mL} \mathrm{Et} 2 \mathrm{O}$, and washed with water $(3 \times 100 \mathrm{~mL})$ and brine $(1 \mathrm{x}$ $100 \mathrm{~mL})$. The combined organic layers were dried over $\mathrm{Na}_{2} \mathrm{SO}_{4}$ and concentrated in vacuo to afford but-3-enyloxy-tert-butyl-dimethyl-silane as a colorless oil (12.54 g, $97 \%$ ), which was used in the next step without further purification.

\footnotetext{
${ }^{1}$ Prepared according to: Goodman, S.N., Jacobsen, E.N. Adv. Synth. Catal. 2002, 344, 953-956.

2 This is a modification of the procedure reported by Baldwin: Baldwin, J.E., Bulger, P.G., Marquez, R.

Tetrahedron, 2002, 58, 5441-5452.
} 
An oven-dried $1000 \mathrm{~mL}$ round-bottom flask equipped with a stirbar was charged with but-3-enyloxy-tert-butyl-dimethyl-silane $(12.0 \mathrm{~g}, 64.4 \mathrm{mmol})$ prepared as described above. Freshly distilled $\mathrm{CH}_{2} \mathrm{Cl}_{2}(250 \mathrm{~mL})$ was added, and the solution was cooled to $78^{\circ} \mathrm{C}$. Ozone was bubbled through the mixture for 45 minutes, until a strong blue color persisted, at which point the solution was sparged with oxygen to remove all excess ozone, as indicated by the disappearance of the blue color. Dimethyl sulfide $(112 \mathrm{~mL}$, $3.0 \mathrm{~mol}$ ) was added, the reaction was allowed to warm to $23^{\circ} \mathrm{C}$, and stirred for $12 \mathrm{~h}$. The reaction mixture was concentrated in vacuo. Flash chromatography (20:1 hexanes/EtOAc) afforded aldehyde 8 as a colorless oil (10.3 g, 85\%) with spectral (HRMS, ${ }^{1} \mathrm{H} \mathrm{NMR},{ }^{13} \mathrm{C} \mathrm{NMR}$ ) properties matching those reported previously. ${ }^{2}$

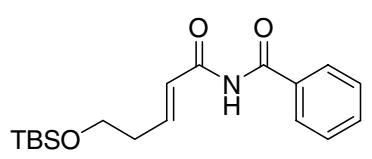

$N$-[5-(tert-Butyl-dimethyl-silanyloxy)-pent-2-enoyl]-benzamide (9). A flame-dried $500 \mathrm{~mL}$ round-bottom flask was charged with phosphonate 7 (13.65 g, $45.6 \mathrm{mmol})$ and a stirbar. Freshly distilled THF was added, and the reaction mixture cooled to $-78^{\circ} \mathrm{C}$ under an atmosphere of nitrogen. After 5 minutes, $n \mathrm{BuLi}(35.8 \mathrm{~mL}, 2.55 \mathrm{M}$ in hexanes, $91.3 \mathrm{mmol}$ ) was added dropwise and the solution was stirred for 15 minutes. The mixture was then warmed to $0^{\circ} \mathrm{C}$, and after 5 min aldehyde 8 (8.59 g, $\left.45.6 \mathrm{mmol}\right)$ was added dropwise. After stirring for $2 \mathrm{~h}$, the reaction mixture was poured onto $0.1 \mathrm{~N} \mathrm{HCl}$ and extracted with $\mathrm{CH}_{2} \mathrm{Cl}_{2}(3 \times 200 \mathrm{~mL})$. The combined organic layers were dried over $\mathrm{Na}_{2} \mathrm{SO}_{4}$ and concentrated in vacuo. Flash chromatography (7:1 hexanes : EtOAc) afforded $\alpha, \beta$-unsaturate imide 9 as a colorless oil (12.77 g, 84\%). Rf: 0.32 (5:1 hexanes : EtOAc); FTIR $\left(\mathrm{CH}_{2} \mathrm{Cl}_{2}\right.$ thin film, $\left.\mathrm{cm}^{-1}\right): 3280(\mathrm{~m}), 2955$ (s), 2930 (s), 2859 (m), 2251 (w), 1722 (s), 1676 (s), 1633 (s), 1504 (m), 1472 (s), 1354 (m), 1252 (s), 1184 (m), 1098 (s), $982(\mathrm{w}), 837(\mathrm{~s}), 777(\mathrm{~m}), 710(\mathrm{~m}) ;{ }^{1} \mathrm{H}$ NMR $\left(500 \mathrm{MHz}, \mathrm{CDCl}_{3}\right) \delta 8.79(\mathrm{~s}, 1 \mathrm{H}), 7.88$ $(\mathrm{d}, J=8.3 \mathrm{~Hz}, 2 \mathrm{H}), 7.60(\mathrm{t}, J=7.3 \mathrm{~Hz}, 1 \mathrm{H}), 7.50(\mathrm{t}, J=7.3,2 \mathrm{H}), 7.16-7.24(\mathrm{~m}, 2 \mathrm{H}), 3.78(\mathrm{t}$, $J=6.2 \mathrm{~Hz}, 2 \mathrm{H}), 2.52(\mathrm{q}, J=7.2 \mathrm{~Hz}, 2 \mathrm{H}), 0.88(\mathrm{~s}, 9 \mathrm{H}), 0.06(\mathrm{~s}, 6 \mathrm{H}) ;{ }^{13} \mathrm{C}$ NMR $(100 \mathrm{MHz}$, $\left.\mathrm{CDCl}_{3}\right) \delta 167.70,166.15,148.71,133.36,133.23,129.11,128.09,124.45,61.84,36.48$, 26.12, 18.52, -5.10; HRMS (EI) Calcd for $\mathrm{C}_{9} \mathrm{H}_{20} \mathrm{O}_{2} \mathrm{Si}\left(\mathrm{MH}^{+}\right)$334.1838, found 334.1828.

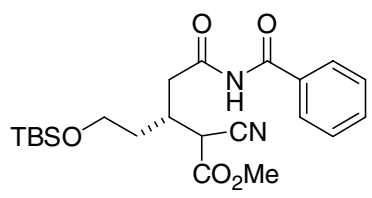

(3R)-5-Benzoylamino-3-[2-(tert-butyl-dimethyl-silanyloxy)ethyl]-2-cyano-5-oxo-pentanoic acid methyl ester $(\underline{\mathbf{1 0}})^{3}$ Unsaturated imide $9(12.0 \mathrm{~g}, 36.0 \mathrm{mmol})$ was placed in a $500 \mathrm{~mL}$ flame-dried round-bottom flask equipped with stirbar, followed by cyclohexane (undistilled, $170 \mathrm{~mL}$ ), methyl cyanoacetate (7.92 $\mathrm{mL}, 90 \mathrm{mmol})$, and $(S, S)-[(\text { salen }) \mathrm{Al}]_{2} \mathrm{O}((S, S)-\mathbf{1 1}, 2.1 \mathrm{~g}, 1.8 \mathrm{mmol}){ }^{3}$ To this rapidly stirred yellow mixture was added $t \mathrm{BuOH}$ (undistilled, $4.13 \mathrm{~mL}, 43.2 \mathrm{mmol}$ ) at $23^{\circ} \mathrm{C}$. After approximately $48 \mathrm{~h}$, the reaction was judged complete by TLC. The reaction mixture was concentrated, and pumped on high vacuum for $6 \mathrm{~h}$ to remove excess methyl cyanoacetate. Flash chromatography (10:1 to 5:1 hexanes : EtOAc) afforded the desired adduct $(14.2 \mathrm{~g}, 91 \%)$ as a yellowish oil, which solidified under high vacuum. This material was determined to be $92 \%$ ee (Chiralcel OD, $1.5 \mathrm{~mL} / \mathrm{min}, 235 \mathrm{~nm}, 10 \%$ IPA/hexanes, $\mathrm{t}_{\mathrm{r}}($ minor $)=11.8 \mathrm{~min}, \mathrm{t}_{\mathrm{r}}($ major $\left.)=20.8 \mathrm{~min}\right)$. Rf: 0.39 (2:1 hexanes :

\footnotetext{
${ }^{3}$ Prepared according to the procedure described in: Taylor, M.S., Jacobsen, E.N. J. Am. Chem. Soc. 2003, 125, 11204-11205.
} 
EtOAc); $\mathrm{m}_{\mathrm{p}}=73-75^{\circ} \mathrm{C} ;[\alpha]^{25}=-15.7^{\circ}\left(\mathrm{c}=1 \mathrm{CHCl}_{3}\right) ;$ FTIR $\left(\mathrm{CH}_{2} \mathrm{Cl}_{2}\right.$ thin film, $\left.\mathrm{cm}^{-1}\right)$ : 3291 (m), 2955 (s), 2930 (s), 2859 (m), 2251 (w), 1751 (s), 1688 (s), 1504 (m), 1472 (s), 1389 (m), 1252 (s), 1181 (m), 1099 (s), 1017 (w), 837 (s), 779 (m), 710 (m); ${ }^{1} \mathrm{H}$ NMR $\left(500 \mathrm{MHz}, \mathrm{CDCl}_{3}, 1.14: 1\right.$ mixture of diastereomers, with signal corresponding to major indicated by *) $\delta 8.90(\mathrm{~s}, 1 \mathrm{H}), 8.84\left(\mathrm{~s}, 1 \mathrm{H}^{*}\right), 7.86\left(\mathrm{~m}, 2 \mathrm{H}, 2 \mathrm{H}^{*}\right), 7.62\left(\mathrm{~m}, 1 \mathrm{H}, 1 \mathrm{H}^{*}\right), 7.51$ $\left(\mathrm{m}, 2 \mathrm{H}, 2 \mathrm{H}^{*}\right), 4.24\left(\mathrm{~d}, J=3.9 \mathrm{~Hz}, 1 \mathrm{H}^{*}\right), 4.21(\mathrm{~d}, J=4.3 \mathrm{~Hz}, 1 \mathrm{H}), 3.82(\mathrm{~s}, 3 \mathrm{H}), 3.80(\mathrm{~s}$, $\left.3 \mathrm{H}^{*}\right), 3.72-3.78\left(\mathrm{~m}, 2 \mathrm{H}, 2 \mathrm{H}^{*}\right), 3.45(\mathrm{dd}, J=3.9,18.6 \mathrm{~Hz}, 1 \mathrm{H}), 3.22-3.26(\mathrm{~m}, 2 \mathrm{H}), 3.12-$ $3.18\left(\mathrm{~m}, 1 \mathrm{H}^{*}\right), 2.99\left(\mathrm{~m}, 2 \mathrm{H}^{*}\right), 1.74-1.82\left(\mathrm{~m}, 2 \mathrm{H}, 2 \mathrm{H}^{*}\right), 0.87\left(\mathrm{~s}, 9 \mathrm{H}, 9 \mathrm{H}^{*}\right), 0.47(\mathrm{~s}, 6 \mathrm{H}$, $\left.6 \mathrm{H}^{*}\right) ;{ }^{13} \mathrm{C} \mathrm{NMR}\left(100 \mathrm{MHz}, \mathrm{CDCl}_{3}\right) \delta 174.88,174.31,166.64,166.38,165.85,165.73$, $133.67,133.61,132.67,132.60,129.26,129.23,128.02,128.00,115.80,115.73,61.40$, 60.47, 53.64, 42.01, 41.58, 39.85, 39.22, 34.78, 34.04, 33.83, 32.53, 26.07, 26.05, 18.42, 18.37, -5.21, -5.31; HRMS Calcd for $\mathrm{C}_{22} \mathrm{H}_{32} \mathrm{~N}_{2} \mathrm{O}_{5} \mathrm{Si}\left(\mathrm{MH}^{+}\right)$433.2159, found 433.2156.

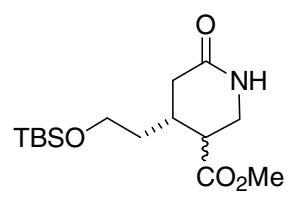

(4R)-[2-(tert-Butyl-dimethyl-silanyloxy)-ethyl]-6-oxo-piperidine-3carboxylic acid methyl ester (12). A $200 \mathrm{~mL}$ flame-dried roundbottom flask was charged with a stirbar, $10(7.5 \mathrm{~g}, 17.3 \mathrm{mmol})$, and toluene (84 mL). Raney nickel (2800 mesh, $800 \mathrm{mg}$ ), then $\mathrm{MeOH}$ (21 $\mathrm{mL}$ ), were added, the flask placed in a stainless steel autoclave, and the resulting suspension subjected to 650 psi hydrogen pressure and heated to $80^{\circ} \mathrm{C}$. After vigorous stirring for $14 \mathrm{~h}$, the solution was filtered through Celite, which was washed sequentially with $\mathrm{MeOH}$ and $\mathrm{CH}_{2} \mathrm{Cl}_{2}$. Solvents were removed in vacuo. Flash chromatography (100\% EtOAc) afforded the desired lactam $(4.87 \mathrm{~g}, 89 \%, 1.7: 1 \mathrm{dr})$ as a clear colorless oil, which solidified under high vacuum. Rf: $0.57\left(10: 1 \mathrm{CH}_{2} \mathrm{Cl}_{2}: \mathrm{MeOH}\right)$; FTIR $\left(\mathrm{CH}_{2} \mathrm{Cl}_{2}\right.$ thin film, $\left.\mathrm{cm}^{-1}\right): 3293(\mathrm{~m}), 3219(\mathrm{~m}), 2953$ (s), 2932 (s), 2859 (m), 2251 (w), 1738 (s), 1670 (s), 1499 (m), 1472 (m), 1437 (m), 1387 (m), 1375 (m), 1362 (m), 1256 (s), 1202 (s), 1169 (m), 1101 (s), 837 (s), 777 (m); ${ }^{1} \mathrm{H}$ NMR (400 MHz, CDCl ${ }_{3}$, 1.7:1 mixture of diastereomers, with signals corresponding to major indicated by $*) \delta$ $6.74\left(\mathrm{~s}, 1 \mathrm{H}^{*}\right), 6.68(\mathrm{~s}, 1 \mathrm{H}), 3.71\left(\mathrm{~s}, 3 \mathrm{H}^{*}\right), 3.69(\mathrm{~s}, 3 \mathrm{H}), 3.61-3.68\left(\mathrm{~m}, 2 \mathrm{H}, 2 \mathrm{H}^{*}\right), 3.55(\mathrm{~m}$, $\left.1 \mathrm{H}, 1 \mathrm{H}^{*}\right), 3.45\left(\mathrm{~m}, 1 \mathrm{H}, 1 \mathrm{H}^{*}\right), 2.89(\mathrm{~m}, 1 \mathrm{H}), 2.64\left(\mathrm{~m}, 1 \mathrm{H}^{*}\right), 2.55$ (dd, J=5.49, $17.5 \mathrm{~Hz}$, $\left.1 \mathrm{H}^{*}\right), 2.45\left(\mathrm{~m}, 3 \mathrm{H}, 1 \mathrm{H}^{*}\right), 2.10\left(\mathrm{q}, J=8.4 \mathrm{~Hz}, 1 \mathrm{H}^{*}\right), 1.63\left(\mathrm{~m}, 1 \mathrm{H}, 1 \mathrm{H}^{*}\right), 1.47(\mathrm{~m}, 1 \mathrm{H}$, $\left.1 \mathrm{H}^{*}\right), 0.86\left(\mathrm{~s}, 9 \mathrm{H}, 9 \mathrm{H}^{*}\right), 0.02\left(\mathrm{~s}, 6 \mathrm{H}, 6 \mathrm{H}^{*}\right) ;{ }^{13} \mathrm{C} \mathrm{NMR}\left(100 \mathrm{MHz}, \mathrm{CDCl}_{3}\right) \delta 173.29$, 172.31, 171.79, 60.38, 60.26, 52.36, 52.14, 44.33, 42.47, 41.77, 41.47, 36.67, 35.57, $35.18,33.78,31.76,30.70,26.09,18.43,-5.20$; HRMS Calcd for $\mathrm{C}_{15} \mathrm{H}_{29} \mathrm{NO}_{4} \mathrm{Si}\left(\mathrm{MH}^{+}\right)$ 316.1944, found 316.1935. The product was immediately dissolved in freshly distilled THF and cooled to $-78^{\circ} \mathrm{C}$ in a flame-dried $100 \mathrm{~mL}$ round-bottom flask. After $5 \mathrm{~min}$, LDA (46.3 $\mathrm{mL}, 46.3 \mathrm{mmol}, 1 \mathrm{M}$ in THF/hexanes) was added dropwise to the reaction mixture, and stirred for 30 minutes. The reaction was quenched at $-78^{\circ} \mathrm{C}$ with $5 \% \mathrm{H}_{2} \mathrm{O}$ in $\mathrm{THF}$, and allowed to warm to room temperature over $20 \mathrm{~min}$. The reaction was partitioned between water and $\mathrm{CH}_{2} \mathrm{Cl}_{2}$, and was extracted with $\mathrm{CH}_{2} \mathrm{Cl}_{2}(3 \times 100 \mathrm{~mL})$, dried $\left(\mathrm{Na}_{2} \mathrm{SO}_{4}\right)$, and concentrated in vacuo to afford a yellowish oil (1:3 dr by GC), which was used in the subsequent step without further purification.

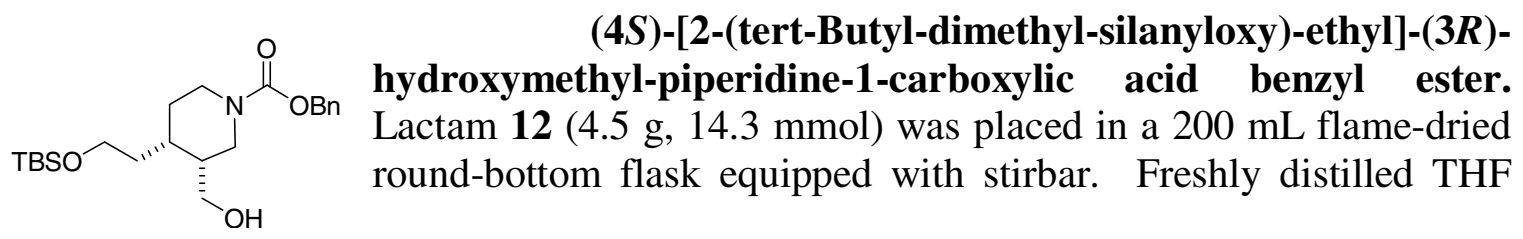


(50 $\mathrm{mL})$ was added via cannula, and the flask cooled to $-78^{\circ} \mathrm{C}$, under a nitrogen atmosphere. LAH (21.4 mL, $21.4 \mathrm{mmol}, 1 \mathrm{M}$ in THF) was added dropwise via syringe over 10 minutes, being careful of both gas evolution and exotherm. The reaction was warmed to $0^{\circ} \mathrm{C}$ for $1 \mathrm{~h}$, and then warmed to $35^{\circ} \mathrm{C}$ for $10 \mathrm{~h}$. The reaction was re-cooled to $0^{\circ} \mathrm{C}$. The reaction was quenched with subsequent addition of water $(850 \mu \mathrm{L}), 15 \% \mathrm{NaOH}$ $(850 \mu \mathrm{L})$, and water $(2.6 \mathrm{~mL})$. The reaction was stirred vigorously at $0^{\circ} \mathrm{C}$ for $5 \mathrm{~min}$, after which $2.0 \mathrm{~g} \mathrm{Na}_{2} \mathrm{SO}_{4}$ was added, and stirred for an additional $5 \mathrm{~min}$. The reaction mixture was filtered through Celite, and the filter pad washed thoroughly with $\mathrm{CH}_{2} \mathrm{Cl}_{2}$ and EtOAc. The crude reaction mixture was concentrated in vacuo to afford the desired piperidine as a clear oil (3.82 $\mathrm{g}, 85 \%$ mass recovery).

The crude material was immediately dissolved in freshly distilled $\mathrm{CH}_{2} \mathrm{Cl}_{2}$ (30 $\mathrm{mL})$, and cooled to $0^{\circ} \mathrm{C}$. Triethylamine $(4.0 \mathrm{~mL}, 28.6 \mathrm{mmol})$ was added, followed by dropwise addition of dibenzyl dicarbonate $(4.5 \mathrm{~g}, 15.7 \mathrm{mmol})$ in $\mathrm{CH}_{2} \mathrm{Cl}_{2}(5 \mathrm{~mL})$. The reaction was stirred at $0^{\circ} \mathrm{C}$ for $3 \mathrm{~h}$, and then warmed to $23^{\circ} \mathrm{C}$ for $1 \mathrm{~h}$. The reaction was concentrated in vacuo. Flash chromatography (4:1 hexanes : EtOAc) afforded the desired cis-product $(2.93 \mathrm{~g}, 50.8 \%)$ as the first eluting diastereomer, and then trans-product (1.09 $\mathrm{g}, 18.9 \%)$ as the second eluting diastereomer, both as light yellow oils. Rf: 0.38 (2:1 hexanes : EtOAc); FTIR $\left(\mathrm{CH}_{2} \mathrm{Cl}_{2}\right.$ thin film, $\left.\mathrm{cm}^{-1}\right)$ : 3459 (s), 2951 (s), 2930 (s), 2859 (m), 1692 (s), 1472 (m), 1441 (s), 1362 (w), 1252 (s), 1215 (m), 1092 (s), 837 (s), 776 (m), $698(\mathrm{w}) ;{ }^{1} \mathrm{H}$ NMR $\left(400 \mathrm{MHz},\left(\mathrm{CD}_{3}\right)_{2} \mathrm{SO}, 90^{\circ} \mathrm{C}\right) \delta 7.20-7.37(\mathrm{~m}, 5 \mathrm{H}), 5.03(\mathrm{~s}, 2 \mathrm{H}), 4.21$ (br, 1H), 3.99 (dd, J=13.2, $4.1 \mathrm{~Hz}, 1 \mathrm{H}), 3.85$ (d, $J=13.2 \mathrm{~Hz}, 1 \mathrm{H}), 3.59$ (q, J=7.2 Hz, 2H), $3.50(\mathrm{~m}, 1 \mathrm{H}), 3.24$ (br, 1H), $2.79(\mathrm{~m}, 1 \mathrm{H}), 2.68(\mathrm{~m}, 1 \mathrm{H}), 1.70(\mathrm{~m}, 2 \mathrm{H}), 1.42(\mathrm{br}, 1 \mathrm{H}), 1.29$ $(\mathrm{m}, 2 \mathrm{H}), 1.13(\mathrm{~m}, 1 \mathrm{H}), 0.84(\mathrm{~s}, 9 \mathrm{H}),-0.02(\mathrm{~s}, 6 \mathrm{H}) ;{ }^{13} \mathrm{C}$ NMR: $\delta$ 155.73, 137.12, 128.70, $128.17,128.03$, 67.25, 62.78, 61.42, 45.97, 43.95, 42.79, 35.64, 33.03, 30.67, 26.18, 18.60, -5.11; HRMS Calcd for $\mathrm{C}_{22} \mathrm{H}_{37} \mathrm{NO}_{4} \mathrm{Si}\left(\mathrm{MH}^{+}\right)$408.2570, found 408.2579.

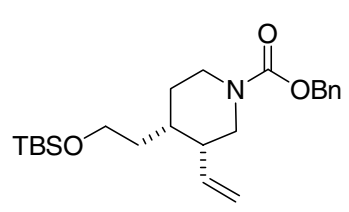

(4S)-[2-(tert-Butyl-dimethyl-silanyloxy)-ethyl]-(3R)-vinylpiperidine-1-carboxylic acid benzyl ester (13). A $100 \mathrm{~mL}$ flamedried round-bottom flask equipped with stirbar was charged with activated $4 \AA \mathrm{MS}(750 \mathrm{mg})$ and $\mathrm{CH}_{2} \mathrm{Cl}_{2}(40 \mathrm{~mL})$. NMO $(433 \mathrm{mg}$, $3.7 \mathrm{mmol})$ and TPAP ( $87 \mathrm{mg}, 246 \mu \mathrm{mol})$ were added together, as a solution in $\mathrm{CH}_{2} \mathrm{Cl}_{2}$. Next, $(4 S)$-[2-(tert-Butyl-dimethyl-silanyloxy)-ethyl]-(3R)hydroxymethyl-piperidine-1-carboxylic acid benzyl ester (1.0 g, $2.46 \mathrm{mmol})$ from above, dissolved in $\mathrm{CH}_{2} \mathrm{Cl}_{2}(4 \mathrm{~mL})$, was added dropwise to the reaction mixture, under an atmosphere of nitrogen. The reaction was stirred at $23^{\circ} \mathrm{C}$ for $1 \mathrm{~h}$. The reaction was diluted with $\mathrm{CH}_{2} \mathrm{Cl}_{2}(50 \mathrm{~mL})$, and filtered through a plug of silica, eluting with $\mathrm{CH}_{2} \mathrm{Cl}_{2}$ and 2:1 hexanes/EtOAc. The combined organics were concentrated in vacuo, to afford the crude aldehyde as a clear oil. This product was used in the subsequent step without further purification.

A flame-dried $200 \mathrm{~mL}$ round-bottom flask equipped with a stirbar was charged with methytriphenylphosphonium bromide $(1.76 \mathrm{~g}, 4.93 \mathrm{mmol})$. Freshly distilled THF $(75 \mathrm{~mL})$ was added, and the reaction mixture cooled to $0^{\circ} \mathrm{C}$ via an external ice bath. $\mathrm{KO} t \mathrm{Bu}(4.93 \mathrm{~mL}, 4.93 \mathrm{mmol}, 1 \mathrm{M}$ in THF) was added dropwise to the reaction mixture. The reaction was stirred at $0^{\circ} \mathrm{C}$ for $15 \mathrm{~min}$, warmed to $23^{\circ} \mathrm{C}$ for $45 \mathrm{~min}$, and then recooled to $0^{\circ} \mathrm{C}$. The crude aldehyde from above, dissolved in $\mathrm{CH}_{2} \mathrm{Cl}_{2}(5 \mathrm{~mL})$ was added dropwise to the reaction mixture. The flask was warmed to $23^{\circ} \mathrm{C}$, and allowed to stir for 
$12 \mathrm{~h}$. The reaction was poured onto water $(150 \mathrm{~mL})$, and extracted with $\mathrm{CH}_{2} \mathrm{Cl}_{2}(2 \times 50$ $\mathrm{mL})$ and $\mathrm{Et}_{2} \mathrm{O}(2 \times 50 \mathrm{~mL})$. The combined organics were washed with water $(50 \mathrm{~mL})$ and brine $(50 \mathrm{~mL})$, dried over $\mathrm{Na}_{2} \mathrm{SO}_{4}$, filtered, and concentrated in vacuo. Flash chromatography (12:1 hexanes : EtOAc) afforded the desired vinyl piperidine $(721 \mathrm{mg}$, $73 \%$ (over 2 steps)) as a clear oil. Rf: 0.24 (12:1 hexanes : EtOAc); FTIR $\left(\mathrm{CH}_{2} \mathrm{Cl}_{2}\right.$ thin film, $\left.\mathrm{cm}^{-1}\right): 2953$ (s), 2930 (s), $2857(\mathrm{~m}), 1705$ (s), 1643 (w), 1468 (m), 1433 (s), 1246 (s), $1200(\mathrm{~m}), 1094(\mathrm{~s}), 916$ (w), 837 (s), 775 (m), 698 (w); ${ }^{1} \mathrm{H}$ NMR $(400 \mathrm{MHz}$, $\left.\left(\mathrm{CD}_{3}\right)_{2} \mathrm{SO}, 90^{\circ} \mathrm{C}\right) \delta 7.27-7.37(\mathrm{~m}, 5 \mathrm{H}), 5.74(\mathrm{ddd}, J=18.6,10.3,8.8 \mathrm{~Hz}, 1 \mathrm{H}), 5.00-5.12$ (m, 4H), $3.88(\mathrm{~d}, J=13.2 \mathrm{~Hz}, 1 \mathrm{H}), 3.80(\mathrm{dd}, J=13.5,3.9 \mathrm{~Hz}, 1 \mathrm{H}), 3.60(\mathrm{t}, J=7 \mathrm{~Hz}, 2 \mathrm{H})$, 3.10 (dd, J=13.5, $3.9 \mathrm{~Hz}, 1 \mathrm{H}), 2.96(\mathrm{~d}, J=13.2 \mathrm{~Hz}, 1 \mathrm{H}), 2.28(\mathrm{q}, J=4.2 \mathrm{~Hz}, 1 \mathrm{H}), 1.76(\mathrm{~m}$, $1 \mathrm{H}), 1.44(\mathrm{~m}, 2 \mathrm{H}), 1.36(\mathrm{~m}, 2 \mathrm{H}), 0.84(\mathrm{~s}, 9 \mathrm{H}),-0.01(\mathrm{~s}, 6 \mathrm{H}) ;{ }^{13} \mathrm{C}$ NMR: $\delta$ 155.41, 139.02, 137.16, 128.69, 128.15, 128.06, 117.51, 67.20, 60.85, 49.36, 46.95, 44.47, 37.12, 36.54, 30.70, 26.18, 18.53, -5.04; HRMS Calcd for $\mathrm{C}_{23} \mathrm{H}_{37} \mathrm{NO}_{3} \mathrm{Si}\left(\mathrm{MH}^{+}\right)$404.2621, found 404.2619.

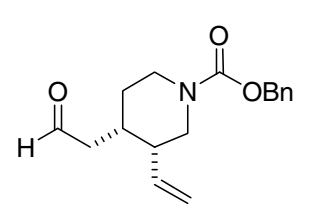

(4S)-(2-Oxo-ethyl)-(3R)-vinyl-piperidine-1-carboxylic acid benzyl ester. A flame-dried $50 \mathrm{~mL}$ round-bottom flask was charged with a stirbar, freshly distilled THF $(10 \mathrm{~mL})$ and $\mathbf{1 3}(700 \mathrm{mg}, 1.74 \mathrm{mmol})$. The flask was cooled to $0^{\circ} \mathrm{C}$ via an external ice bath, and TBAF (3.46 $\mathrm{mL}, 3.46 \mathrm{mmol}, 1 \mathrm{M}$ in THF) was added dropwise to the reaction mixture. The reaction was allowed to stir for $4 \mathrm{~h}$, at which point it was poured onto water $(50 \mathrm{~mL})$, extracted with $\mathrm{CH}_{2} \mathrm{Cl}_{2}(3 \times 50 \mathrm{~mL})$, dried over $\mathrm{Na}_{2} \mathrm{SO}_{4}$, filtered, and concentrated in vacuo. The crude primary alcohol was used in the subsequent step without further purification.

A $50 \mathrm{~mL}$ flame-dried round-bottom flask equipped with stirbar was charged with activated $4 \AA \mathrm{MS}(380 \mathrm{mg})$ and $\mathrm{CH}_{2} \mathrm{Cl}_{2}(10 \mathrm{~mL})$. NMO (305 mg, $\left.2.6 \mathrm{mmol}\right)$ and TPAP (62 mg, $173 \mu \mathrm{mol}$ ) were added together, as a solution in $\mathrm{CH}_{2} \mathrm{Cl}_{2}$. Next, the crude alcohol dissolved in $\mathrm{CH}_{2} \mathrm{Cl}_{2}(2 \mathrm{~mL})$ was added dropwise to the reaction mixture, under an atmosphere of nitrogen. The reaction was stirred at $23^{\circ} \mathrm{C}$ for $2 \mathrm{~h}$. The solvent volume was reduced to $3 \mathrm{~mL}$, and the reaction loaded directly onto a silica column. Flash chromatography (3:1 hexanes : EtOAc) afforded the desired aldehyde $(428 \mathrm{mg}, 86 \%$ (over 2 steps)) as a slightly yellow, clear oil. Rf: 0.46 (2:1 hexanes : EtOAc); FTIR $\left(\mathrm{CH}_{2} \mathrm{Cl}_{2}\right.$ thin film, $\left.\mathrm{cm}^{-1}\right)$ : $3515(\mathrm{w}), 3068(\mathrm{w}), 3032(\mathrm{w}), 2915(\mathrm{~s}), 2855(\mathrm{~m}), 2726(\mathrm{w})$, 1720 (m), 1703 (s), 1643(w), 1499 (w), 1468 (m), 1433 (s), $1273(\mathrm{~m}), 1242(\mathrm{~s}), 1198(\mathrm{~m})$, $1122(\mathrm{~m}), 999(\mathrm{w}), 763(\mathrm{w}), 698(\mathrm{w}) ;{ }^{1} \mathrm{H}$ NMR $\left(500 \mathrm{MHz},\left(\mathrm{CD}_{3}\right)_{2} \mathrm{SO}, 90^{\circ} \mathrm{C}\right) \delta 9.68(\mathrm{~s}$, $1 \mathrm{H}), 7.29-7.36(\mathrm{~m}, 5 \mathrm{H}), 5.74$ (ddd, $J=17.2,10.7,8.8 \mathrm{~Hz}, 1 \mathrm{H}), 5.03-5.10(\mathrm{~m}, 4 \mathrm{H}), 3.87$ (d, $J=13.2 \mathrm{~Hz}, 1 \mathrm{H}), 3.80(\mathrm{dd}, J=13.5,3.9 \mathrm{~Hz}, 1 \mathrm{H}), 3.20(\mathrm{dd}, J=13.5,3.9 \mathrm{~Hz}, 1 \mathrm{H}), 3.10(\mathrm{~d}$, $J=13.2 \mathrm{~Hz}, 1 \mathrm{H}), 2.38(\mathrm{~m}, 2 \mathrm{H}), 2.28(\mathrm{~m}, 2 \mathrm{H}), 1.51(\mathrm{~m}, 1 \mathrm{H}), 1.37(\mathrm{~m}, 1 \mathrm{H}) ;{ }^{13} \mathrm{C}$ NMR: $\delta$ 201.90, 155.32, 138.08, 137.01, 128.72, 128.22, 128.09, 118.72, 67.31, 49.05, 48.32, 46.77, 44.21, 35.10, 31.44; HRMS Calcd for $\mathrm{C}_{17} \mathrm{H}_{21} \mathrm{NO}_{3}\left(\mathrm{MH}^{+}\right)$288.1599, found 288.1589 .

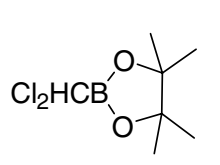

2-Dichloromethyl-4,4,5,5-tetramethyl-[1,3,2] dioxaborolane $\quad(\underline{15}) .{ }^{4} \quad \mathrm{~A}$ flame-dried $200 \mathrm{~mL}$ round-bottom flask equipped with a stirbar was cooled to $-100^{\circ} \mathrm{C}$ via an $\mathrm{EtOH} / \mathrm{LN}_{2}$ bath. The flask was charged with a solution of $\mathrm{CH}_{2} \mathrm{Cl}_{2}(3.53 \mathrm{~mL}, 55 \mathrm{mmol})$ in THF $(100 \mathrm{~mL}) . n \mathrm{BuLi}(20.6 \mathrm{~mL}, 2.43 \mathrm{M}$ in 
hexanes, $50 \mathrm{mmol}$ ) was added dropwise over a period of $40 \mathrm{~min}$. The resulting suspension of dichloromethyllithium was stirred for an additional $30 \mathrm{~min}$ and then trimethylborate $(6.25 \mathrm{ml}, 55 \mathrm{mmol})$ was added in one portion. After $30 \mathrm{~min}$, the reaction mixture was hydrolyzed with $10 \mathrm{~mL}$ of $5 \mathrm{~N} \mathrm{HCl}$. The solution was allowed to reach $23^{\circ} \mathrm{C}$, the organic layer separated, and the aqueous layer extracted with ether $(2 \times 25 \mathrm{~mL})$. The combined organic layers were concentrated in vacuo, to afford crude dichloromethylboronic acid as a viscous reddish-brown oil. The crude product was taken up in $110 \mathrm{~mL}$ of benzene, and pinacol $(6.50 \mathrm{~g}, 55 \mathrm{mmol})$ was added in one portion. The biphasic mixture was heated to reflux under a nitrogen atmosphere. After $48 \mathrm{~h}$, the homogeneous yellow solution was cooled to room temperature and fractionally distilled to afford the desired product $(10.1 \mathrm{~g}, 87 \%)$ as a colorless oil with spectral (HRMS, ${ }^{1} \mathrm{H}$ $\left.\mathrm{NMR},{ }^{13} \mathrm{C} \mathrm{NMR}\right)$ properties matching those reported previously. ${ }^{4}$

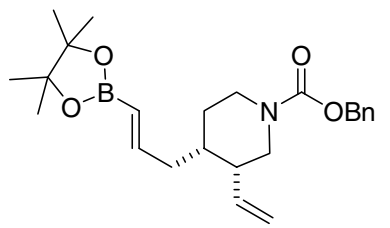

(4R)-[3-(4,4,5,5-Tetramethyl-[1,3,2]dioxaborolan-2-yl)-allyl](3R)-vinyl-piperidine-1-carboxylic acid benzyl ester (14). Anhydrous $\mathrm{CrCl}_{2}(1.02 \mathrm{~g}, 8.3 \mathrm{mmol})$ was suspended in freshly distilled THF $(10 \mathrm{~mL})$ in a flame-dried $50 \mathrm{~mL}$ round-bottom flask. A solution of (4S)-(2-Oxo-ethyl)-(3R)-vinyl-piperidine-1carboxylic acid benzyl ester (300 mg, $1.04 \mathrm{mmol}$ ) and 15 (439 mg, $2.08 \mathrm{mmol}$ ) dissolved in THF ( $2 \mathrm{~mL}$ ) were added quickly, followed by dropwise addition of LiI (561 mg, 4.16 mmol) in THF ( $1 \mathrm{~mL})$. The reaction flask was then covered with foil to exclude light, and stirred vigorously for $12 \mathrm{~h}$. The reaction was poured on to ice/water, extracted with hexanes $(2 \times 25 \mathrm{~mL})$ and $\mathrm{CH}_{2} \mathrm{Cl}_{2}(2 \times 25 \mathrm{~mL})$, dried over $\mathrm{Na}_{2} \mathrm{SO}_{4}$, filtered, and concentrated in vacuo. Flash chromatography (7:1 hexanes : EtOAc) afforded the desired $(E)$-vinyl boronate ester $(338 \mathrm{mg}, 79 \%$, dr: $>20: 1)$ as a faint yellow oil. Rf: 0.23 (7:1 hexanes : EtOAc); FTIR $\left(\mathrm{CH}_{2} \mathrm{Cl}_{2}\right.$ thin film, $\left.\mathrm{cm}^{-1}\right)$ : 3515 (w), 3068 (w), 2978 (s), 2932 (s), 2855 (m), 1707 (s), 1693 (s), 1640 (m), 1433 (s), 1366 (s), 1321 (m), 1240 (m), 1229 (m), 1146 (m), 1117 (m), $997(\mathrm{~m}), 970(\mathrm{~m}), 920(\mathrm{w}), 849(\mathrm{w}), 764(\mathrm{w}), 698(\mathrm{w}) ;{ }^{1} \mathrm{H}$ NMR $\left(500 \mathrm{MHz},\left(\mathrm{CD}_{3}\right)_{2} \mathrm{SO}, 90^{\circ} \mathrm{C}\right) \quad \delta$ 7.29-7.36 (m, 5H), $6.47(\mathrm{dt}, J=18.1,6.4 \mathrm{~Hz}, 1 \mathrm{H}), 5.75$ (ddd, $J=18.1,10.3,8.8 \mathrm{~Hz}, 1 \mathrm{H}), 5.34$ (d, $J=18.1 \mathrm{~Hz}, 1 \mathrm{H}), 5.03-5.10$ (m, 4H), 3.92 (d, $J=13.2 \mathrm{~Hz}, 1 \mathrm{H}), 3.84(\mathrm{dd}, J=13.5,3.9 \mathrm{~Hz}, 1 \mathrm{H}), 3.14(\mathrm{dd}, J=13.5,3.9 \mathrm{~Hz}, 1 \mathrm{H}), 3.05$ (d, $J=13.2 \mathrm{~Hz}, 1 \mathrm{H}), 2.33$ (br, 1H), $2.08(\mathrm{~m}, 1 \mathrm{H}), 1.99$ (m, 1H), 1.80 (m, 1H), $1.46(\mathrm{~m}, 1 \mathrm{H})$, $1.33(\mathrm{q}, J=12.1,1 \mathrm{H}), 1.20(\mathrm{~s}, 12 \mathrm{H}) ;{ }^{13} \mathrm{C}$ NMR: $\delta 155.39,151.97,138.60,137.13,128.70$, 128.15, 128.05, 117.86, 95.01, 83.31, 67.22, 49.17, 46.44, 44.44, 40.07, 39.76, 30.49, 25.04; HRMS Calcd for $\mathrm{C}_{24} \mathrm{H}_{34} \mathrm{BNO}_{4}\left(\mathrm{MH}^{+}\right)$412.2659, found 412.2657.

Br 4-Bromo-6-methoxyquinoline (18). A flame-dried microwave reactor
sessel equipped with dibromotriphenylphosphorane (360 $\mathrm{mg}, 0.86 \mathrm{mmol})$, and sealed. 6methoxy-1H-quinolin-4-one $(100 \mathrm{mg}, 0.57 \mathrm{mmol}$, prepared according to literature procedure $\left.{ }^{5}\right)$ dissolved in $\mathrm{CH}_{3} \mathrm{CN}(3 \mathrm{~mL})$ was added via syringe, and the reaction subjected to microwave irradiation at $170^{\circ} \mathrm{C}$ for $15 \mathrm{~min}$. The resulting reaction mixture was concentrated in vacuo. Flash chromatography (1:2 hexanes : EtOAc) afforded the desired quinoline (114 $\mathrm{mg}, 84 \%$ ) as an off-white solid. Alternatively, 9 can be prepared in similar yield, resorting to longer reaction times under non-microwave conditions. A

\footnotetext{
${ }^{4}$ Prepared according to: Wuts, P.G., Thompson, P.A. J. Organometallic Chem. 1982, 234, 137-141.
} 
flame-dried $50 \mathrm{~mL}$ round-bottom flask was charged with dibromotriphenylphosphorane $(1.80 \mathrm{~g}, 4.3 \mathrm{mmol})$, a stirbar, and a condenser. $\mathrm{CH}_{3} \mathrm{CN}(15 \mathrm{~mL})$ was added, followed by 6-methoxy-1H-quinolin-4-one $(500 \mathrm{mg}, 2.85 \mathrm{mmol}$, prepared according to literature procedure ${ }^{5}$ ) dissolved in $\mathrm{CH}_{3} \mathrm{CN}(2 \mathrm{~mL})$. Under nitrogen, the reaction was brought to reflux for 12-24 h. The crude reaction mixture was concentrated in vacuo. Flash chromatography (1:2 hexanes : EtOAc) afforded the desired quinoline $(550 \mathrm{mg}, 81 \%)$ as an off-white solid. Rf: $0.68\left(10: 1 \mathrm{CH}_{2} \mathrm{Cl}_{2}: \mathrm{MeOH}\right) ; \mathrm{m}_{\mathrm{p}}=78-80^{\circ} \mathrm{C}$; FTIR $\left(\mathrm{CH}_{2} \mathrm{Cl}_{2}\right.$ thin film, $\mathrm{cm}^{-1}$ ): 3421 (m), 3084 (w), 2963 (w), 1620 (s), 1574 (w), 1501 (s), 1425 (m), 1354 (m), 1263 (m), 1232 (s), 1163 (w), 1066 (w), 845 (s), 818 (m), 716 (m); ${ }^{1} \mathrm{H}$ NMR (400 $\left.\mathrm{MHz} \mathrm{CDCl}_{3}\right) \delta 8.51(\mathrm{~d}, J=4.4 \mathrm{~Hz}, 1 \mathrm{H}), 7.98(\mathrm{~d}, J=9.2 \mathrm{~Hz}, 1 \mathrm{H}), 7.65(\mathrm{~d}, J=4.8 \mathrm{~Hz}, 1 \mathrm{H})$, 7.36-7.41 (m, 2H), 3.95 (s, 3H); ${ }^{13} \mathrm{C}$ NMR (100 MHz, $\left.\mathrm{CDCl}_{3}\right) \delta$ 159.14, 147.27, 145.27, 132.67, 131.70, 129.23, 125.49, 123.52, 104.57, 55.92; HRMS (EI) Calcd for $\mathrm{C}_{10} \mathrm{H}_{8} \mathrm{BrNO}\left(\mathrm{MH}^{+}\right)$237.9789, 239.9769, found 237.9867, 239.9829.

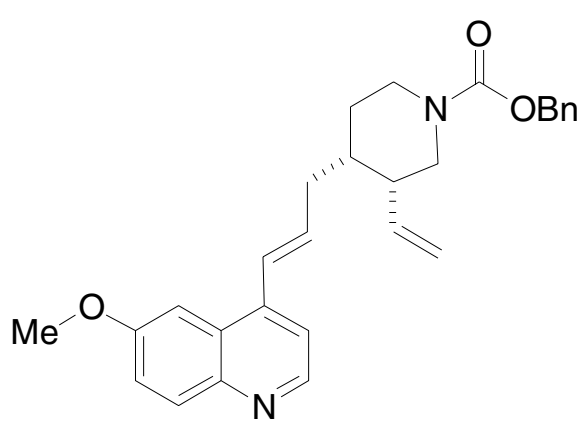

(4R)-[3-(6-Methoxy-quinolin-4-yl)-allyl]-(3R)vinyl-piperidine-1-carboxylic acid benzyl ester (20). A flame-dried $25 \mathrm{~mL}$ round-bottom flask equipped with stirbar was charged with $\mathrm{Pd}(\mathrm{OAc})_{2}$ (2.8 mg, $12.5 \mu \mathrm{mol}), 19$ (10.3 mg, $25 \mu \mathrm{mol}),(E)-$ vinyl boronic ester 14 (205 $\mathrm{mg}, 0.50 \mathrm{mmol})$, and ground $\mathrm{K}_{3} \mathrm{PO}_{4} \mathrm{H}_{2} \mathrm{O}(230 \mathrm{mg}, 1.0 \mathrm{mmol})$. The flask was sealed with a septum, evacuated, back-filled with nitrogen, and freshly distilled THF (3 mL) was added via syringe. The reaction mixture was allowed to stir at room temperature for 2 min. Then quinoline 18 (120 mg, $0.50 \mathrm{mmol})$ was added dropwise in THF (1 mL) via syringe. The reaction mixture was stirred at $23^{\circ} \mathrm{C}$ for $16 \mathrm{~h}$. Diethyl ether $(20 \mathrm{~mL})$ was added, and the dilute reaction mixture filtered through Celite, eluting with diethyl ether $(25 \mathrm{~mL})$ and $10 \% \mathrm{MeOH} / \mathrm{CH}_{2} \mathrm{Cl}_{2}(50 \mathrm{~mL})$, and then concentrated in vacuo. Flash chromatography (1:1 hexanes : EtOAc) afforded the desired trans-olefin $(197 \mathrm{mg}, 89 \%$, dr: >20:1) as a clear oil. Rf: 0.38 (1:1 hexanes : EtOAc); FTIR $\left(\mathrm{CH}_{2} \mathrm{Cl}_{2}\right.$ thin film, $\left.\mathrm{cm}^{-1}\right): 3420$ (w), 2926 (s), 2855 (m), 1697 (s), 1620 (w), 1507 (w), 1470 (w), 1433 (m), 1260 (m), 1231 (s), $1098(\mathrm{w}), 1028(\mathrm{~m}) ; 696(\mathrm{w}) ;{ }^{1} \mathrm{H}$ NMR $\left(500 \mathrm{MHz},\left(\mathrm{CD}_{3}\right)_{2} \mathrm{SO}, 90^{\circ} \mathrm{C}\right) \delta 8.67(\mathrm{~d}, J=4.4 \mathrm{~Hz}$, $1 \mathrm{H}), 7.94(\mathrm{~d}, J=9.2 \mathrm{~Hz}, 1 \mathrm{H}), 7.53(\mathrm{dd}, J=4.4 \mathrm{~Hz}, 1 \mathrm{H}), 7.20-7.50(\mathrm{~m}, 7 \mathrm{H}), 7.18$ (d, $J=15.6$ $\mathrm{Hz}, 1 \mathrm{H}), 6.55$ (dt, J=15.6, 7.3 Hz, 1H), $5.87(\mathrm{~m}, 1 \mathrm{H}), 5.05-5.23(\mathrm{~m}, 4 \mathrm{H}), 4.01$ (d, $J=13.6$ $\mathrm{Hz}, 1 \mathrm{H}), 3.97(\mathrm{~s}, 3 \mathrm{H}), 3.84(\mathrm{dd}, J=13.5,3.9 \mathrm{~Hz}, 1 \mathrm{H}), 3.21(\mathrm{dd}, J=13.5,3.9 \mathrm{~Hz}, 1 \mathrm{H}), 3.06$ (d, $J=13.2 \mathrm{~Hz}, 1 \mathrm{H}), 2.27-2.38(\mathrm{~m}, 2 \mathrm{H}), 1.99(\mathrm{~m}, 1 \mathrm{H}), 1.64(\mathrm{dd}, 13.2,4.4 \mathrm{~Hz}, 1 \mathrm{H}), 1.51$ $(\mathrm{m}, 1 \mathrm{H}), 1.35(\mathrm{~m}, 1 \mathrm{H}) ;{ }^{13} \mathrm{C}$ NMR $\left(100 \mathrm{MHz}, \mathrm{CDCl}_{3}\right) \delta 157.90,155.81,147.89,144.86$, $142.17,137.10,135.68,135.57,131.64,128.69$, 128.17, 128.05, 127.34, 127.01, 121.92, 117.92, 117.77, 101.77, 67.27, 55.75, 48.95, 44.27, 42.84, 39.26, 37.62, 27.57; HRMS Calcd for $\mathrm{C}_{28} \mathrm{H}_{30} \mathrm{~N}_{2} \mathrm{O}_{3}\left(\mathrm{MH}^{+}\right)$443.2334, found 443.2337.

\footnotetext{
${ }^{5}$ Prepared according to: Nicolaou, K.C., Gross, J.L., Kerr, M.A. J. Heterocyclic Chem. 1996, 33, 735-746.
} 


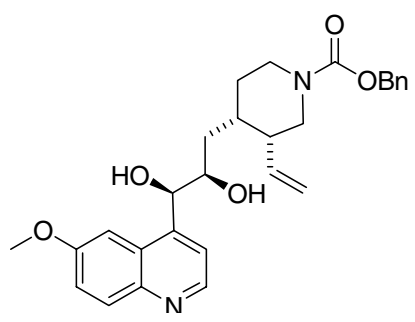

reaction stirred for $12 \mathrm{~h}$

(4S)-[2,3-(R,R)-Dihydroxy-3-(6-methoxy-quinolin-4-yl)propyl]-(3R)-vinyl-piperidine-1-carboxylic acid benzyl ester. $\quad$ A $10 \mathrm{~mL}$ round-bottom flask was charged with a stir bar, ADmix- $\beta$ (241 mg), and methanesulfonamide (50 mg, $0.53 \mathrm{mmol})$. Water $(1 \mathrm{~mL})$ and $t \mathrm{BuOH}(1 \mathrm{~mL})$ were added, and the reaction cooled to $0^{\circ} \mathrm{C}$. Olefin $20(75 \mathrm{mg}, 0.17 \mathrm{mmol})$ was added in one portion dissolved in $t \mathrm{BuOH}(500 \mu \mathrm{L})$ and the allowed to warm to $23^{\circ} \mathrm{C}$, with stirring continued for an additional hour. The reaction was poured onto water $(25 \mathrm{~mL})$, extracted with $\mathrm{CH}_{2} \mathrm{Cl}_{2}(3 \times 25 \mathrm{~mL})$, dried over $\mathrm{Na}_{2} \mathrm{SO}_{4}$, filtered, and concentrated in vacuo. Flash chromatography $\left(20: 1 \mathrm{CH}_{2} \mathrm{Cl}_{2}: \mathrm{MeOH}\right)$ afforded the desired $(R, R)$ diol $(71 \mathrm{mg}, 88 \%, \mathrm{dr}>96: 4)$ as an off-white solid. Rf: 0.48 (10:1 $\left.\mathrm{CH}_{2} \mathrm{Cl}_{2}: \mathrm{MeOH}\right) ; \mathrm{m}_{\mathrm{p}}=138-141^{\circ} \mathrm{C}$; FTIR $\left(\mathrm{CH}_{2} \mathrm{Cl}_{2}\right.$ thin film, $\left.\mathrm{cm}^{-1}\right): 3391$ (s), 2926 (s), 2857 (m), 1694 (s), 1622 (w), 1591 (w), 1510 (w), 1472 (w), 1435 (s), 1242 (s), 1142 (w), 1096 (m), 1082 (m), 1028 (m); 918 (w), 760 (w), 696 (w); ${ }^{1} \mathrm{H}$ NMR (500 MHz, $\left.\left(\mathrm{CD}_{3}\right)_{2} \mathrm{SO}, 90^{\circ} \mathrm{C}, 12 \mathrm{mg}\right) \delta 8.67(\mathrm{~d}, J=4.4 \mathrm{~Hz}, 1 \mathrm{H}), 7.92(\mathrm{~d}, J=8.9 \mathrm{~Hz}, 1 \mathrm{H}), 7.50(\mathrm{~m}, 2 \mathrm{H})$, $7.35(\mathrm{dd}, J=9.3,2.9 \mathrm{~Hz}, 1 \mathrm{H}), 7.26-7.34(\mathrm{~m}, 5 \mathrm{H}), 5.58(\mathrm{~m}, 1 \mathrm{H}), 5.17(\mathrm{~d}, J=3.9 \mathrm{~Hz}, 1 \mathrm{H})$, 4.99-5.10(m, 3H), $4.83(\mathrm{~d}, J=3.4 \mathrm{~Hz} 1 \mathrm{H}), 4.31(\mathrm{~m}, 1 \mathrm{H}), 3.93(\mathrm{~d}, J=13.2 \mathrm{~Hz}, 1 \mathrm{H}), 3.91$ (s, $3 \mathrm{H}), 3.85$ (dd, $J=13.5,3.9 \mathrm{~Hz}, 1 \mathrm{H}), 3.01(\mathrm{dd}, J=13.5,3.9 \mathrm{~Hz}, 1 \mathrm{H}), 2.87(\mathrm{~d}, J=13.2 \mathrm{~Hz}$, $1 \mathrm{H}), 2.28(\mathrm{~m}, 1 \mathrm{H}), 1.88(\mathrm{~m}, 1 \mathrm{H}), 1.40(\mathrm{~m}, 1 \mathrm{H}), 1.26-1.37(\mathrm{~m}, 3 \mathrm{H}) ;{ }^{13} \mathrm{C}$ NMR $(100 \mathrm{MHz}$, $\left.\mathrm{CDCl}_{3}, 36 \mathrm{mg}\right) \delta 157.88,155.75,147.32,146.31,143.86,136.99,135.50,131.25,128.65$, $128.13,127.95,126.97,121.47,119.40,117.55,102.05,73.69,71.23,67.22,55.78$, 49.50, 44.47, 37.01, 35.02, 29.95, 28.62; HRMS Calcd for $\mathrm{C}_{28} \mathrm{H}_{32} \mathrm{~N}_{2} \mathrm{O}_{5}\left(\mathrm{MH}^{+}\right)$477.2389, found 477.2380 .

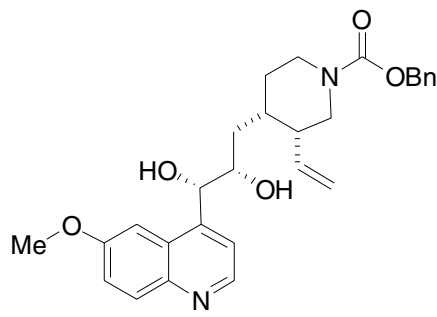

$(4 S)-[2,3-(S, S)-D i h y d r o x y-3-(6-m e t h o x y-q u i n o l i n-4-y l)-$ propyl]-(3R)-vinyl-piperidine-1-carboxylic acid benzyl ester. ${ }^{5}$ A $10 \mathrm{~mL}$ round-bottom flask was charged with a stir bar, ADmix- $\alpha$ (241 mg), and methanesulfonamide (50 mg, $0.51 \mathrm{mmol})$. Water $(1 \mathrm{~mL})$ and $t \mathrm{BuOH}(1 \mathrm{~mL})$ were added, and the reaction cooled to $0^{\circ} \mathrm{C}$. Olefin $20(75 \mathrm{mg}, 0.17 \mathrm{mmol})$ was added in one portion dissolved in $t \mathrm{BuOH}(500 \mu \mathrm{L})$ and the reaction stirred for $12 \mathrm{~h}$. Sodium sulfite $(300 \mathrm{mg})$ was added and the reaction was allowed to warm to $23^{\circ} \mathrm{C}$, with stirring continued for an additional hour. The reaction was poured onto water ( $25 \mathrm{~mL})$, extracted with $\mathrm{CH}_{2} \mathrm{Cl}_{2}(3 \times 25 \mathrm{~mL})$, dried over $\mathrm{Na}_{2} \mathrm{SO}_{4}$, filtered, and concentrated in vacuo. Flash chromatography $\left(20: 1 \mathrm{CH}_{2} \mathrm{Cl}_{2}: \mathrm{MeOH}\right)$ afforded the desired $(S, S)$ diol $(70 \mathrm{mg}, 86 \%, \mathrm{dr}>96: 4)$ as an off-white solid. Rf: 0.48 (10:1 $\left.\mathrm{CH}_{2} \mathrm{Cl}_{2}: \mathrm{MeOH}\right) ; \mathrm{m}_{\mathrm{p}}=136-139^{\circ} \mathrm{C}$; FTIR $\left(\mathrm{CH}_{2} \mathrm{Cl}_{2}\right.$ thin film, $\left.\mathrm{cm}^{-1}\right): 3391$ (s), 2928 (s), $2861(\mathrm{~m}), 1692(\mathrm{~s}), 1620(\mathrm{w}), 1591(\mathrm{w}), 1510(\mathrm{w}), 1472(\mathrm{~m}), 1435(\mathrm{~s}), 1364(\mathrm{w})$, 1240 (s), 1176 (w), 1144 (w), 1094 (m), 1049 (m), 1026 (s); 916 (w), 762 (w), 698 (w); ${ }^{1} \mathrm{H}$ NMR $\left(500 \mathrm{MHz},\left(\mathrm{CD}_{3}\right)_{2} \mathrm{SO}, 90^{\circ} \mathrm{C}, 13 \mathrm{mg}\right) \delta 8.67(\mathrm{~d}, J=4.4 \mathrm{~Hz}, 1 \mathrm{H}), 7.92(\mathrm{~d}, J=8.9$ $\mathrm{Hz}, 1 \mathrm{H}), 7.49$ (m, 2H), 7.35 (dd, J=9.3, $2.9 \mathrm{~Hz}, 1 \mathrm{H}), 7.26-7.34$ (m, 5H), 5.68 (ddd, $J=18.0,10.7,8.3 \mathrm{~Hz}, 1 \mathrm{H}), 5.10-5.17$ (m, 2H), 4.94-5.07 (m, 3H), 4.27 (m, 1H), 3.91 (s,

${ }^{5}$ Sharpless, K.B., Amberg, W., Bennani, Y.L., Crispino, G.A., Hartung, J., Jeong, K., Kwong, H., Morikawa, K., Wang, Z., Xu, D., Zhang, X., J. Org. Chem. 1992, 57, 10, 2768-2771. 
$3 \mathrm{H}), 3.81(\mathrm{~d}, J=13.2 \mathrm{~Hz}, 1 \mathrm{H}), 3.74(\mathrm{dd}, J=13.5,3.9 \mathrm{~Hz}, 1 \mathrm{H}), 3.12(\mathrm{dd}, J=13.5,3.9 \mathrm{~Hz}$, $1 \mathrm{H}), 2.92(\mathrm{~d}, J=13.2 \mathrm{~Hz}, 1 \mathrm{H}), 2.25(\mathrm{~m}, 1 \mathrm{H}), 1.90(\mathrm{~m}, 1 \mathrm{H}), 1.40-1.48(\mathrm{~m}, 2 \mathrm{H}), 1.16-1.28$ $(\mathrm{m}, 2 \mathrm{H}) ;{ }^{13} \mathrm{C} \mathrm{NMR}\left(100 \mathrm{MHz}, \mathrm{CDCl}_{3}, 20 \mathrm{mg}\right) \delta 157.88,155.74,147.37,146.62,143.78$, 136.98, 135.83, 131.22, 128.66, 128.17, 128.00, 126.85, 121.71, 119.07, 117.49, 101.46, 73.39, 71.49, 67.25, 55.70, 49.98, 43.86, 37.44, 34.98, 29.92, 26.62; HRMS Calcd for $\mathrm{C}_{28} \mathrm{H}_{32} \mathrm{~N}_{2} \mathrm{O}_{5}\left(\mathrm{MH}^{+}\right)$477.2389, found 477.2390.

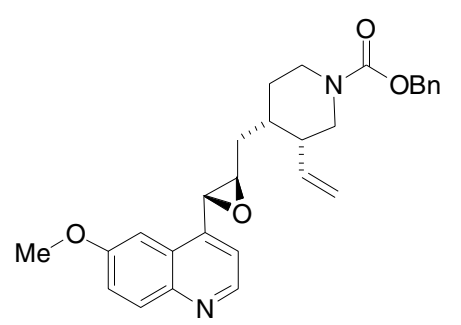

(4S)-[3-(6-Methoxy-quinolin-4-yl)-( $R, R)$-oxiranylmethyl](3R)-vinyl-piperidine-1-carboxylic acid benzyl ester (21). A flame-dried $10 \mathrm{~mL}$ round-bottom flask equipped with a stirbar was charged with $(4 S)-[2,3-(R, R)$-Dihydroxy-3-(6methoxy-quinolin-4-yl)-propyl]-(3R)-vinyl-piperidine-1carboxylic acid benzyl ester $(68 \mathrm{mg}, 0.143 \mathrm{mmol})$ and freshly distilled $\mathrm{CH}_{2} \mathrm{Cl}_{2}(2 \mathrm{~mL})$. The flask was evacuated and backfilled with nitrogen. Trimethylorthoacetate $(55 \mu \mathrm{L}, 0.43 \mathrm{mmol})$ and PPTS $(1.8 \mathrm{mg}, 7.2$ $\mu \mathrm{mol}$ ) were added, and the reaction stirred for $12 \mathrm{~h}$. The volatiles were removed in vacuo, and the flask pumped on high vacuum for $2 \mathrm{~min}$ to remove excess $\mathrm{MeOH}$. The white residue was re-dissolved in freshly distilled $\mathrm{CH}_{2} \mathrm{Cl}_{2}(2 \mathrm{~mL})$ under nitrogen, and cooled to $0^{\circ} \mathrm{C}$. Acetyl bromide $(32 \mu \mathrm{L}, 0.43 \mathrm{mmol}$ ) was added via syringe, the reaction warmed to $23^{\circ} \mathrm{C}$, and stirred for $6 \mathrm{~h}$. The volatiles were removed in vacuo, and the orange residue was redissolved in anhydrous $\mathrm{MeOH}(2 \mathrm{~mL}) . \mathrm{K}_{2} \mathrm{CO}_{3}(60 \mathrm{mg}, 0.43 \mathrm{mmol})$ was added in one portion, and the heterogeneous mixture was stirred for $2 \mathrm{~h}$. The reaction was poured directly onto saturated $\mathrm{NH}_{4} \mathrm{Cl}$, extracted with $\mathrm{CH}_{2} \mathrm{Cl}_{2}(3 \times 25 \mathrm{~mL})$, dried over $\mathrm{Na}_{2} \mathrm{SO}_{4}$, filtered, and concentrated in vacuo. Flash chromatography (50:1 $\left.\mathrm{CH}_{2} \mathrm{Cl}_{2}: \mathrm{MeOH}\right)$ afforded the desired $(R, R)$ epoxide $(53 \mathrm{mg}, 81 \%)$ as a clear oil. Rf: 0.55 $\left(10: 1 \mathrm{CH}_{2} \mathrm{Cl}_{2}: \mathrm{MeOH}\right) ;[\alpha]_{\mathrm{D}}^{25}=-19.2^{\circ}\left(\mathrm{c}=1.5 \mathrm{CHCl}_{3}\right) ; \mathrm{FTIR}\left(\mathrm{CH}_{2} \mathrm{Cl}_{2}\right.$ thin film, $\left.\mathrm{cm}^{-1}\right)$ : 2930 (s), 2857 (m), 1697 (s), $1620(\mathrm{w}), 1593$ (w), 1508 (w), $1474(\mathrm{w}), 1433(\mathrm{~s}), 1366$ (w), $1242(\mathrm{~s}), 1099(\mathrm{~m}), 1028(\mathrm{~m}) ; 916(\mathrm{w}), 856(\mathrm{~m}), 829(\mathrm{w}), 764(\mathrm{w}), 696(\mathrm{w}) ;{ }^{1} \mathrm{H}$ NMR $\left(500 \mathrm{MHz},\left(\mathrm{CD}_{3}\right)_{2} \mathrm{SO}, 90^{\circ} \mathrm{C}\right) \delta 8.68(\mathrm{~d}, J=4.4 \mathrm{~Hz}, 1 \mathrm{H}), 7.96(\mathrm{~d}, J=9.3 \mathrm{~Hz}, 1 \mathrm{H}), 7.48(\mathrm{~d}$, $J=2.7,1 \mathrm{H}), 7.43(\mathrm{dd}, 9.3,2.6,1 \mathrm{H}), 7.27-7.36(\mathrm{~m}, 5 \mathrm{H}), 7.25(\mathrm{~d}, J=4.4 \mathrm{~Hz}, 1 \mathrm{H}), 5.85$ (ddd, $J=18.5,10.2,8.3 \mathrm{~Hz}, 1 \mathrm{H}), 5.05-5.18(\mathrm{~m}, 4 \mathrm{H}), 4.41(\mathrm{~d}, J=1.9 \mathrm{~Hz}, 1 \mathrm{H}), 3.95(\mathrm{~s}, 3 \mathrm{H}), 3.94$ (d, $J=13.2 \mathrm{~Hz}, 1 \mathrm{H}), 3.87(\mathrm{dd}, J=13.2,3.9 \mathrm{~Hz}, 1 \mathrm{H}), 3.20(\mathrm{dd}, J=13.2,3.9 \mathrm{~Hz}, 1 \mathrm{H}), 3.08$ (m, 1H), $3.03(\mathrm{~d}, J=13.2 \mathrm{~Hz}, 1 \mathrm{H}), 2.46(\mathrm{~m}, 1 \mathrm{H}), 2.05(\mathrm{~m}, 1 \mathrm{H}), 1.89(\mathrm{dt}, J=14.2,5.4 \mathrm{~Hz}$, $1 \mathrm{H}), 1.58-1.68(\mathrm{~m}, 2 \mathrm{H}), 1.52(\mathrm{~m}, 1 \mathrm{H}) ;{ }^{13} \mathrm{C}$ NMR $\left(100 \mathrm{MHz}, \mathrm{CDCl}_{3}\right) \delta$ 158.22, 155.77, $148.17,144.10,141.88,137.07,135.56,132.00,128.69,128.19,128.06,127.60,121.80$, $118.09,117.04,101.25,67.30,61.29,55.85,55.61,49.15,44.05,37.35,36.03,29.98$, 28.02; HRMS Calcd for $\mathrm{C}_{28} \mathrm{H}_{30} \mathrm{~N}_{2} \mathrm{O}_{4}\left(\mathrm{MH}^{+}\right)$459.2284, found 459.2285.

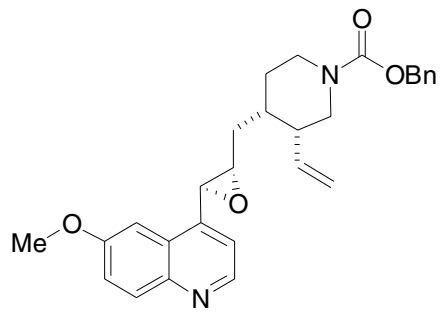

(4S)-[3-(6-Methoxy-quinolin-4-yl)-(S,S)-oxiranylmethyl](3R)-vinyl-piperidine-1-carboxylic acid benzyl ester (22). A flame-dried $10 \mathrm{~mL}$ round-bottom flask equipped with stirbar was charged with (4S)-[2,3-(S,S)-Dihydroxy-3-(6methoxy-quinolin-4-yl)-propyl]-(3R)-vinyl-piperidine-1carboxylic acid benzyl ester $(65 \mathrm{mg}, 0.136 \mathrm{mmol})$ and freshly distilled $\mathrm{CH}_{2} \mathrm{Cl}_{2}(2 \mathrm{~mL})$. The flask was evacuated 
and back-filled with nitrogen. Trimethylorthoacetate (53 $\mu \mathrm{L}, 0.41 \mathrm{mmol})$ and PPTS $(1.7$ $\mathrm{mg}, 6.8 \mu \mathrm{mol}$ ) were added, and the reaction stirred for $12 \mathrm{~h}$. The volatiles were removed in vacuo, and the flask pumped on high vacuum for 2 min to remove excess $\mathrm{MeOH}$. The white residue was re-dissolved in freshly distilled $\mathrm{CH}_{2} \mathrm{Cl}_{2}(2 \mathrm{~mL})$ under nitrogen, and cooled to $0^{\circ} \mathrm{C}$. Acetyl bromide $(30.5 \mu \mathrm{L}, 0.41 \mathrm{mmol})$ was added via syringe, the reaction warmed to $23^{\circ} \mathrm{C}$, and stirred for $6 \mathrm{~h}$. The volatiles were removed in vacuo, and the orange residue was redissolved in anhydrous $\mathrm{MeOH}(2 \mathrm{~mL}) . \mathrm{K}_{2} \mathrm{CO}_{3}(57 \mathrm{mg}, 0.41 \mathrm{mmol})$ was added in one portion, and the heterogeneous mixture was stirred for 2 hours. The reaction was poured directly onto saturated $\mathrm{NH}_{4} \mathrm{Cl}$, extracted with $\mathrm{CH}_{2} \mathrm{Cl}_{2}(3 \times 25 \mathrm{~mL})$, dried over $\mathrm{Na}_{2} \mathrm{SO}_{4}$, filtered, and concentrated in vacuo. Flash chromatography (50:1 $\left.\mathrm{CH}_{2} \mathrm{Cl}_{2}: \mathrm{MeOH}\right)$ afforded the desired $(S, S)$ epoxide $(48 \mathrm{mg}, 77 \%)$ as a clear oil. Rf: 0.55 $\left(10: 1 \mathrm{CH}_{2} \mathrm{Cl}_{2}: \mathrm{MeOH}\right) ;[\alpha]_{\mathrm{D}}^{22}=+60.0^{\circ}\left(\mathrm{c}=1.5 \mathrm{CHCl}_{3}\right) ;$ FTIR $\left(\mathrm{CH}_{2} \mathrm{Cl}_{2}\right.$ thin film, $\left.\mathrm{cm}^{-1}\right)$ : 2930 (s), 2857 (m), 1697 (s), 1620 (w), 1593 (w), 1508 (w), 1474 (w), 1433 (s), 1366 (w), 1242 (s), $1099(\mathrm{~m}), 1028(\mathrm{~m}) ; 918(\mathrm{w}), 856(\mathrm{~m}), 829(\mathrm{w}), 762(\mathrm{w}), 698(\mathrm{w}) ;{ }^{1} \mathrm{H}$ NMR $\left(500 \mathrm{MHz},\left(\mathrm{CD}_{3}\right)_{2} \mathrm{SO}, 90^{\circ} \mathrm{C}\right) \delta 8.68(\mathrm{~d}, J=4.4 \mathrm{~Hz}, 1 \mathrm{H}), 7.96(\mathrm{~d}, J=9.3 \mathrm{~Hz}, 1 \mathrm{H}), 7.50(\mathrm{~d}$, $J=2.5,1 \mathrm{H}), 7.43(\mathrm{dd}, 9.3,2.4,1 \mathrm{H}), 7.27-7.36(\mathrm{~m}, 5 \mathrm{H}), 7.25(\mathrm{~d}, J=4.4 \mathrm{~Hz}, 1 \mathrm{H}), 5.84$ (ddd, $J=18.5,10.3,8.3 \mathrm{~Hz}, 1 \mathrm{H}), 5.05-5.18$ (m, 4H), 4.46 (d, $J=1.9 \mathrm{~Hz}, 1 \mathrm{H}), 3.96$ (d, $J=13.2 \mathrm{~Hz}$, $1 \mathrm{H}), 3.94(\mathrm{~s}, 3 \mathrm{H}), 3.85(\mathrm{dd}, J=13.2,3.9 \mathrm{~Hz}, 1 \mathrm{H}), 3.20(\mathrm{dd}, J=13.2,3.9 \mathrm{~Hz}, 1 \mathrm{H}), 3.06(\mathrm{~m}$, $1 \mathrm{H}), 3.01(\mathrm{~d}, J=13.2 \mathrm{~Hz}, 1 \mathrm{H}), 2.42(\mathrm{~m}, 1 \mathrm{H}), 2.04(\mathrm{~m}, 1 \mathrm{H}), 1.80(\mathrm{dt}, J=14.2,5.8 \mathrm{~Hz}, 1 \mathrm{H})$, 1.60-1.72 (m, 2H), $1.52(\mathrm{~m}, 1 \mathrm{H}) ;{ }^{13} \mathrm{C}$ NMR $\left(100 \mathrm{MHz}, \mathrm{CDCl}_{3}\right) \delta 158.23,155.77,148.18$, 144.07, 141.88, 137.03, 135.15, 132.01, 128.69, 128.19, 128.06, 127.55, 121.80, 118.25, 116.87, 101.15, 67.31, 61.63, 56.09, 55.82, 49.13, 44.08, 37.05, 36.42, 29.93, 27.45; HRMS Calcd for $\mathrm{C}_{28} \mathrm{H}_{30} \mathrm{~N}_{2} \mathrm{O}_{4}\left(\mathrm{MH}^{+}\right)$459.2284, found 459.2276.

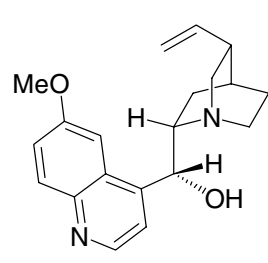

Quinine (1). A flame-dried $10 \mathrm{~mL}$ round-bottom flask was charged with a stirbar and epoxide 21 (50 $\mathrm{mg}, 0.11 \mathrm{mmol})$. The epoxide was dissolved in $\mathrm{CH}_{2} \mathrm{Cl}_{2}(1 \mathrm{~mL})$ and cooled to $0^{\circ} \mathrm{C}$. $\mathrm{Et}_{2} \mathrm{AlCl}(182 \mu \mathrm{L}, 1.8 \mathrm{M}$ in toluene, $0.33 \mathrm{mmol}$ ) was added dropwise via syringe, and the solution stirred for 2 hours. Next, thioanisole $(77 \mu \mathrm{L}, 0.66 \mathrm{mmol})$ was added via syringe, the reaction slowly warmed to $23^{\circ} \mathrm{C}$, and stirred for an additional $6 \mathrm{~h}$. The reaction was diluted with $\mathrm{Et}_{2} \mathrm{O}(9 \mathrm{~mL})$, and poured onto a $1 \mathrm{~N}$ solution of $\mathrm{NaOH}$. The organic layer was extracted, and subsequently washed with $\mathrm{NaHCO}_{3}$ (sat'd aqueous), and brine. The aqueous layers were combined, and extracted with $\mathrm{CH}_{2} \mathrm{Cl}_{2}$ (3 x $\left.20 \mathrm{~mL}\right)$. The combined organics were dried over $\mathrm{Na}_{2} \mathrm{SO}_{4}$, filtered, and concentrated in vacuo to afford the crude piperidine. A microwave reaction vessel was charged with the resulting crude residue dissolved in freshly distilled $\mathrm{CH}_{3} \mathrm{CN}(2.5 \mathrm{~mL})$. The vessel was sealed and subjected to microwave irradiation at $185^{\circ} \mathrm{C}$ for $20 \mathrm{~min}$, and the solvent concentrated in vacuo. Flash chromatography $\left(0.75 \%\right.$ TEA in $10: 1 \mathrm{CH}_{2} \mathrm{Cl}_{2}$ : $\mathrm{MeOH}$ ) afforded pure quinine (24 mg, 68\%), with spectral (HRMS, ${ }^{1} \mathrm{H}$ NMR, ${ }^{13} \mathrm{C} \mathrm{NMR}$ ) properties matching those of an authentic sample from Acros. Rf: $0.21\left(10: 1 \mathrm{CH}_{2} \mathrm{Cl}_{2}\right.$ : $\mathrm{MeOH}) ;[\alpha]^{26}=-154.1^{\circ}(\mathrm{c}=1 \mathrm{EtOH}) ; \mathrm{m}_{\mathrm{p}}=172-175^{\circ} \mathrm{C}$; FTIR $\left(\mathrm{CH}_{2} \mathrm{Cl}_{2}\right.$ thin film, $\left.\mathrm{cm}^{-1}\right)$ : 3273 (s), 2932 (s), 2874 (m), 1620 (s), 1591 (w), 1510 (s), 1470 (w), 1452 (w), 1433 (w), 1242 (s), 1229 (m), 1134 (w), 1103 (w), 1030 (m), 941 (w), 826 (w); ${ }^{1} \mathrm{H}$ NMR (500 MHz, $\left.\mathrm{CDCl}_{3}, 14 \mathrm{mg}\right) \delta 8.63(\mathrm{~d}, J=4.4 \mathrm{~Hz}, 1 \mathrm{H}), 7.95(\mathrm{~d}, J=8.8 \mathrm{~Hz}, 1 \mathrm{H}), 7.49(\mathrm{~d}, J=4.9 \mathrm{~Hz}, 1 \mathrm{H})$, 7.30 (dd, $J=9.3,2.5 \mathrm{~Hz}, 1 \mathrm{H}), 7.22(\mathrm{~d}, J=2.5 \mathrm{~Hz}, 1 \mathrm{H}), 5.74$ (ddd, $J=17.6,10.3,7.8 \mathrm{~Hz}$, $1 \mathrm{H}), 5.55(\mathrm{~d}, J=3.9 \mathrm{~Hz}, 1 \mathrm{H}), 4.94(\mathrm{~m}, 2 \mathrm{H}), 3.82(\mathrm{~s}, 3 \mathrm{H}), 3.46(\mathrm{~m}, 1 \mathrm{H}), 3.13(\mathrm{~m}, 1 \mathrm{H}), 3.08$ 
(dd, $J=13.7,10.3 \mathrm{~Hz}, 1 \mathrm{H}), 2.66(\mathrm{~m}, 2 \mathrm{H}), 2.27(\mathrm{br}, 1 \mathrm{H}), 1.81(\mathrm{~m}, 1 \mathrm{H}), 1.72(\mathrm{~m}, 2 \mathrm{H}), 1.51$ (m, $2 \mathrm{H}) ;{ }^{13} \mathrm{C}$ NMR $\left(100 \mathrm{MHz}, \mathrm{CDCl}_{3}, 24 \mathrm{mg}\right) \delta 157.89,148.30,147.57,144.15,141.91$, $131.47,126.74,121.64,118.73,114.69,101.52$, 71.70, 60.13, 57.08, 55.90, 43.43, 40.05, 28.04, 27.67, 21.62; HRMS Calcd for $\mathrm{C}_{20} \mathrm{H}_{24} \mathrm{~N}_{2} \mathrm{O}_{2}\left(\mathrm{MH}^{+}\right)$325.1916, found 325.1915.
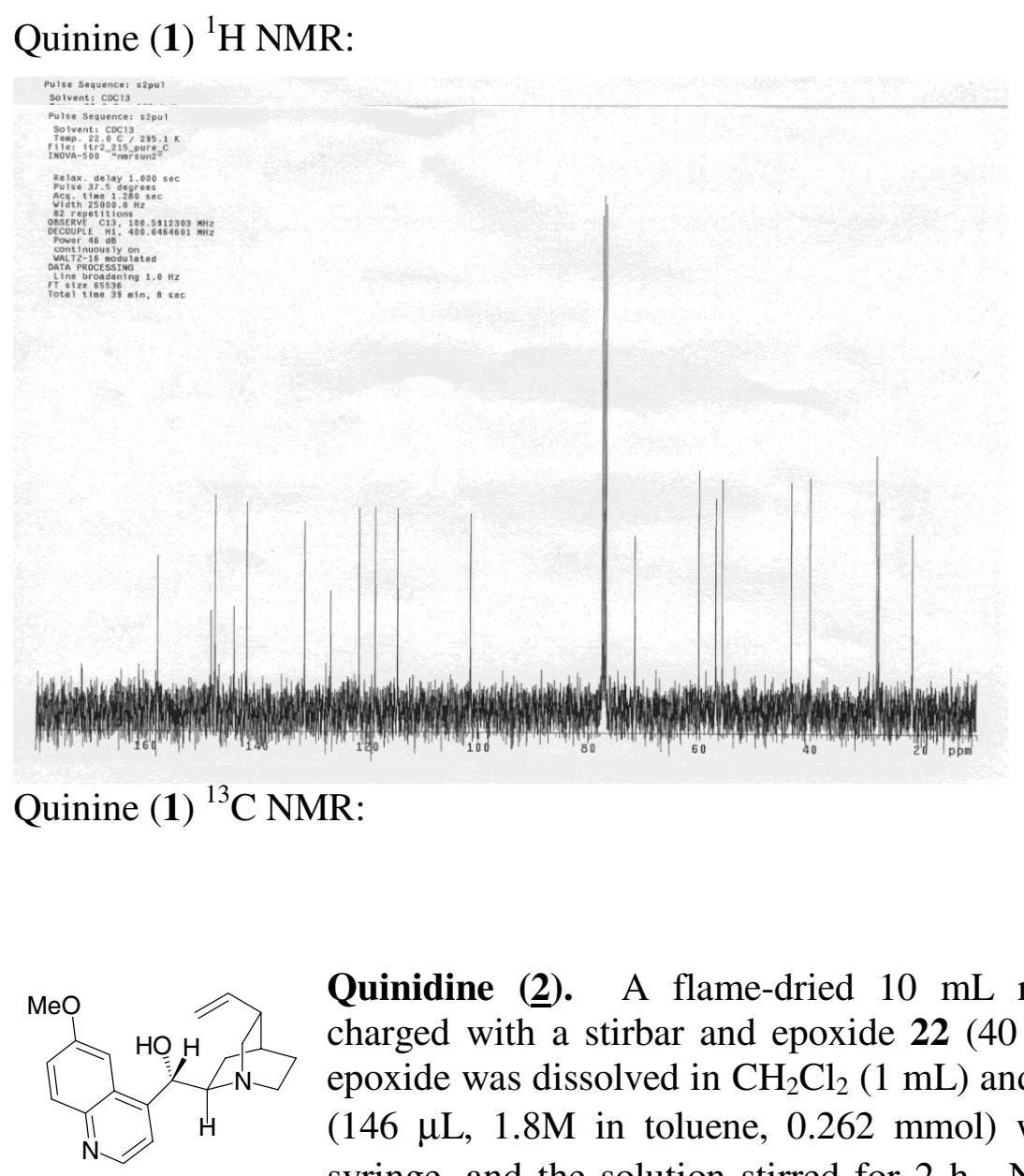

Quinidine (2). A flame-dried $10 \mathrm{~mL}$ round-bottom flask was charged with a stirbar and epoxide $22(40 \mathrm{mg}, 0.087 \mathrm{mmol})$. The epoxide was dissolved in $\mathrm{CH}_{2} \mathrm{Cl}_{2}(1 \mathrm{~mL})$ and cooled to $0^{\circ} \mathrm{C}$. $\mathrm{Et}_{2} \mathrm{AlCl}$ $(146 \mu \mathrm{L}, 1.8 \mathrm{M}$ in toluene, $0.262 \mathrm{mmol}$ ) was added dropwise via syringe, and the solution stirred for $2 \mathrm{~h}$. Next, thioanisole $(61 \mu \mathrm{L}$, $0.523 \mathrm{mmol}$ ) was added via syringe, the reaction slowly warmed to $23^{\circ} \mathrm{C}$, and stirred for an additional $6 \mathrm{~h}$. The reaction was diluted with $\mathrm{Et}_{2} \mathrm{O}(9 \mathrm{~mL})$, and poured onto a $1 \mathrm{~N}$ solution of $\mathrm{NaOH}$. The organic layer was extracted, and subsequently washed with $\mathrm{NaHCO}_{3}$ (sat'd aqueous), and brine. The aqueous layers were combined, and extracted with $\mathrm{CH}_{2} \mathrm{Cl}_{2}(3 \times 20 \mathrm{~mL})$. The combined organics were dried over $\mathrm{Na}_{2} \mathrm{SO}_{4}$, filtered, and concentrated in vacuo to afford the crude piperidine. A microwave reaction vessel was charged with the resulting crude residue dissolved in freshly distilled $\mathrm{CH}_{3} \mathrm{CN}(2.5 \mathrm{~mL})$. The vessel was sealed and subjected to microwave irradiation at $185^{\circ} \mathrm{C}$ for $20 \mathrm{~min}$, and the solvent concentrated in vacuo. Flash chromatography $\left(0.75 \%\right.$ TEA in $10: 1 \mathrm{CH}_{2} \mathrm{Cl}_{2}$ : $\mathrm{MeOH})$ afforded pure quinidine $(21 \mathrm{mg}, 74 \%)$, with spectral (HRMS, ${ }^{1} \mathrm{H}$ NMR, ${ }^{13} \mathrm{C}$ NMR) properties matching those of an authentic sample from Avocado. Rf: 0.21 (10:1 $\left.\mathrm{CH}_{2} \mathrm{Cl}_{2}: \mathrm{MeOH}\right) ;[\alpha]^{26}{ }_{\mathrm{D}}=+236^{\circ}$ (c=1 EtOH); $\mathrm{m}_{\mathrm{p}}=170-172^{\circ} \mathrm{C} ;$ FTIR $\left(\mathrm{CH}_{2} \mathrm{Cl}_{2}\right.$ thin film, $\mathrm{cm}^{-1}$ ): $3221(\mathrm{~s}), 2936(\mathrm{~s}), 2870(\mathrm{~m}), 1620(\mathrm{~s}), 1510(\mathrm{~s}), 1472(\mathrm{w}), 1454(\mathrm{w}), 1433(\mathrm{w})$, $1242(\mathrm{~s}), 1229(\mathrm{~m}), 1107$ (w), $1030(\mathrm{~m}), 831(\mathrm{w}) ;{ }^{1} \mathrm{H}$ NMR (500 MHz, $\left.\mathrm{CDCl}_{3}, 6 \mathrm{mg}\right) \delta$ $8.74(\mathrm{~d}, J=4.4 \mathrm{~Hz}, 1 \mathrm{H}), 8.00(\mathrm{~d}, J=9.3 \mathrm{~Hz}, 1 \mathrm{H}), 7.56(\mathrm{~d}, J=4.9 \mathrm{~Hz}, 1 \mathrm{H}), 7.33$ (dd, $J=9.3$, 
$2.9 \mathrm{~Hz}, 1 \mathrm{H}), 7.23(\mathrm{~d}, J=2.5 \mathrm{~Hz}, 1 \mathrm{H}), 5.98$ (ddd, $J=17.8,10.3,7.5 \mathrm{~Hz}, 1 \mathrm{H}), 5.72(\mathrm{br}, 1 \mathrm{H})$, 5.02-5.07 (m, 2H), $3.90(\mathrm{~s}, 3 \mathrm{H}), 3.34(\mathrm{br}, 1 \mathrm{H}), 3.15(\mathrm{~m}, 1 \mathrm{H}), 2.96(\mathrm{~m}, 2 \mathrm{H}), 2.82(\mathrm{~m}, 1 \mathrm{H})$, $2.28(\mathrm{~m}, 1 \mathrm{H}), 2.04(\mathrm{~m}, 1 \mathrm{H}), 1.80(\mathrm{~m}, 1 \mathrm{H}), 1.57(\mathrm{~m}, 2 \mathrm{H}), 1.22(\mathrm{~m}, 1 \mathrm{H}) ;{ }^{13} \mathrm{C}$ NMR $(100$ $\left.\mathrm{MHz}, \mathrm{CDCl}_{3}\right) \delta 158.74,148.61,147.56,144.07,140.99,131.41,126.79,121.56,118.66$, 114.66, 101.53, 72.00, 60.02, 55.78, 50.36, 49.87, 40.39, 28.48, 26.68, 21.77; HRMS Calcd for $\mathrm{C}_{20} \mathrm{H}_{24} \mathrm{~N}_{2} \mathrm{O}_{2}\left(\mathrm{MH}^{+}\right)$325.1916, found 325.1925.

Quinidine (2) ${ }^{1} \mathrm{H}$ NMR:

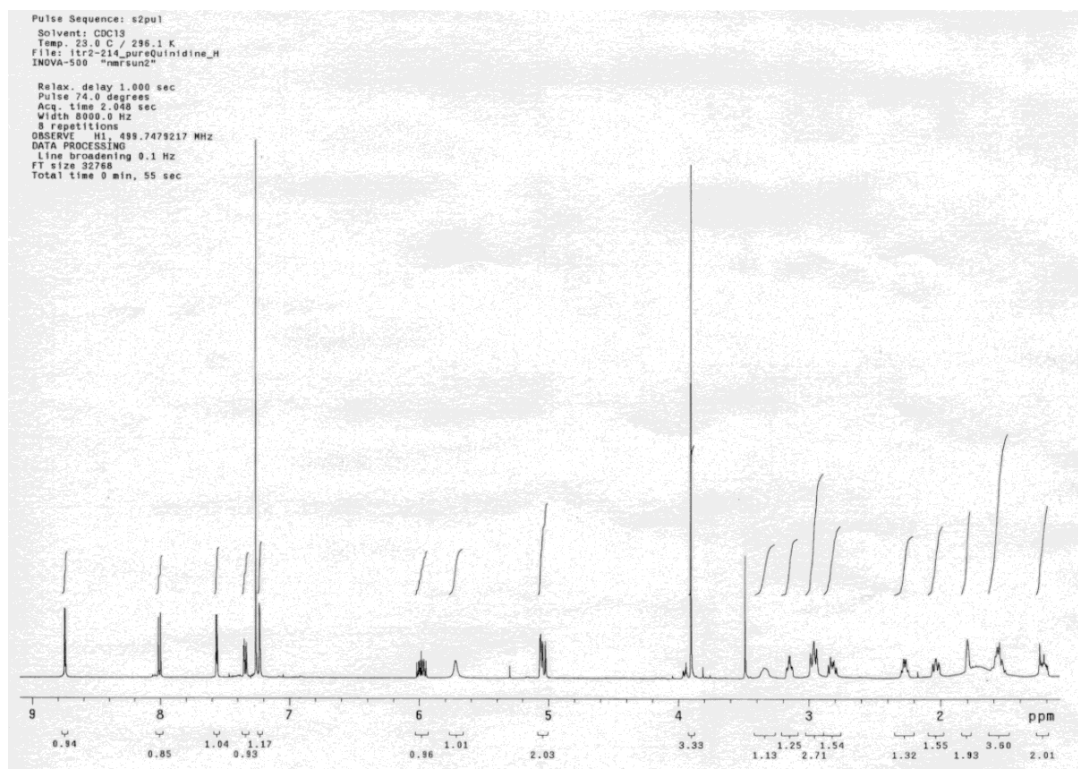

Quinidine (2) ${ }^{13} \mathrm{C}$ NMR:
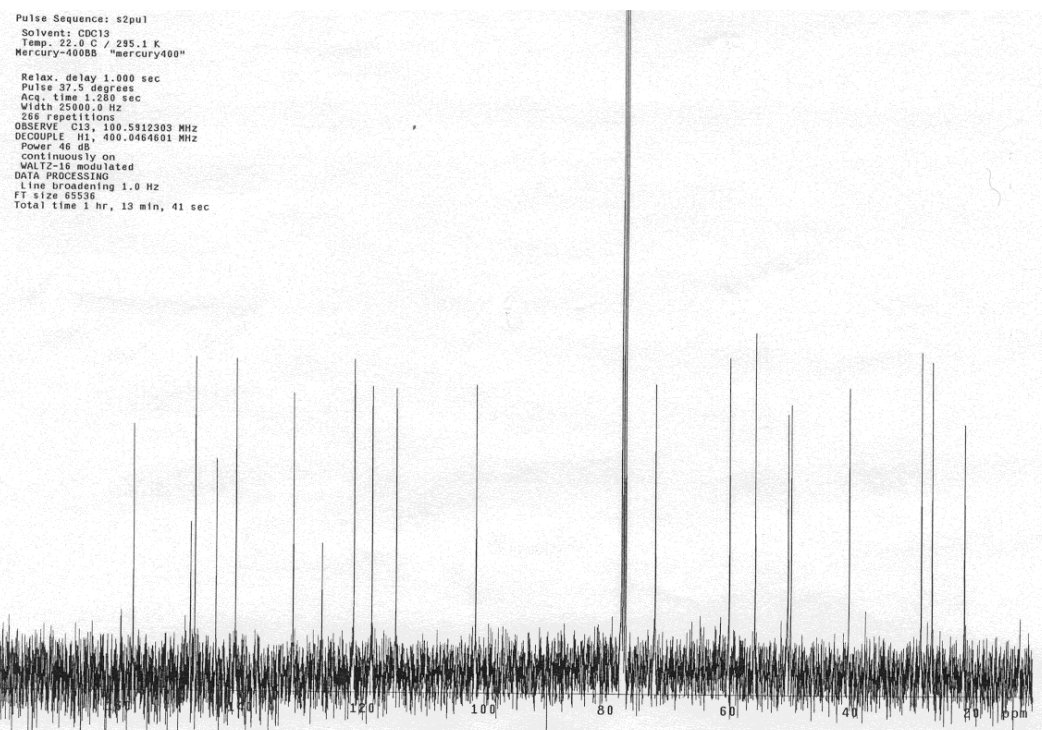
Determination of enantiomeric purity for (3R)-5-Benzoylamino-3-[2-(tert-butyldimethyl-silanyloxy)-ethyl]-2-cyano-5-oxo-pentanoic acid methyl ester (7).

Column conditions: Chiralcel OD, $1.5 \mathrm{~mL} / \mathrm{min}, 235 \mathrm{~nm}, 10 \%$ IPA/hexanes

\section{Racemic Product:}
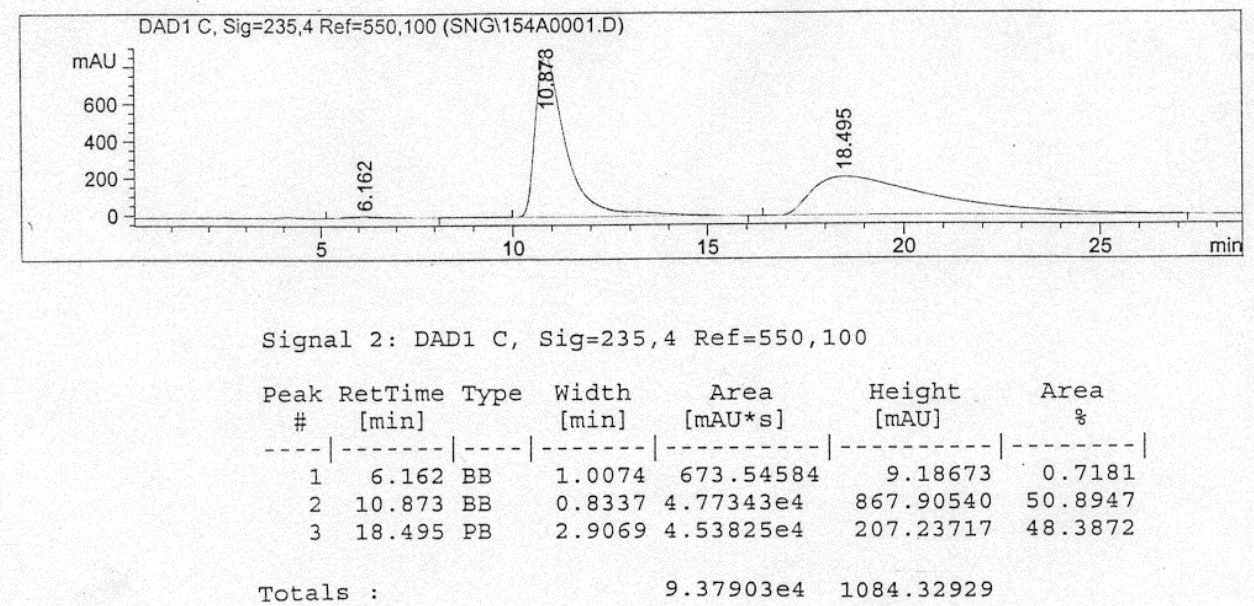

(7):

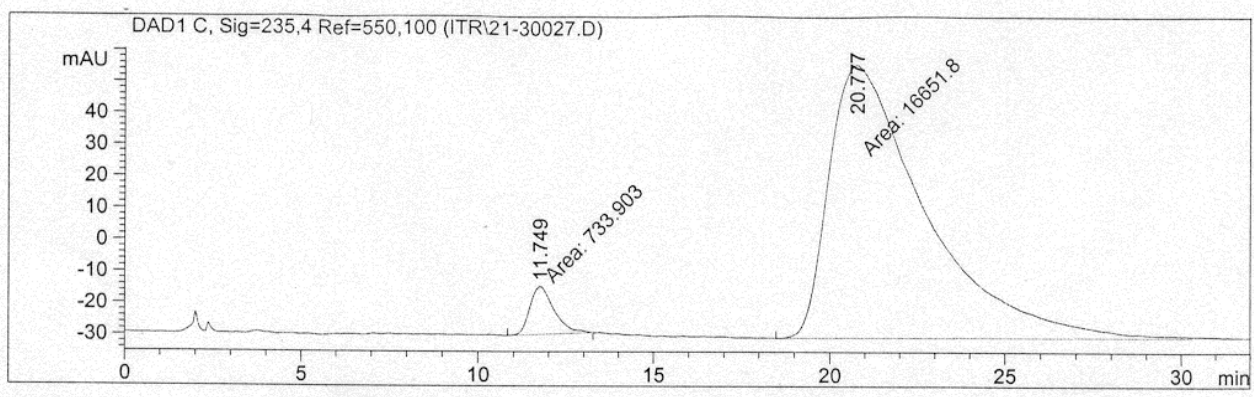

Signal 2: DAD1 C, Sig $=235,4$ Ref $=550,100$

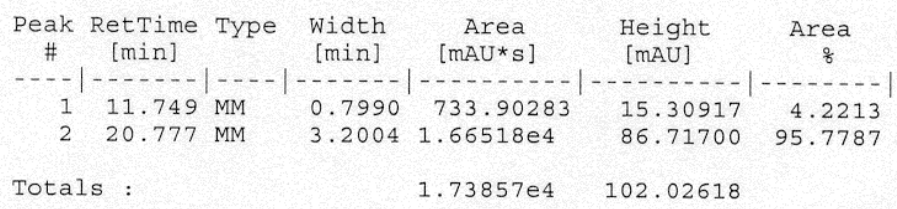


Determination of diastereomeric ratios for (4R)-[2-(tert-Butyl-dimethyl-silanyloxy)ethyl]-6-oxo-piperidine-3-carboxylic acid methyl ester (15).

Column conditions: $\mathrm{HP}-5$ capillary column (30m $\times 0.32 \mathrm{~mm}$ i.d. $\times 0.25 \mathrm{~m}$ film) using $\mathrm{H}_{2}$ as a carrier gas. Start temp.: $100^{\circ} \mathrm{C}(10 \mathrm{~min})$; ramp to $180^{\circ} \mathrm{C}\left(15^{\circ} \mathrm{C} / \mathrm{min}\right)$; ramp to $280^{\circ} \mathrm{C}$ $\left(25^{\circ} \mathrm{C} / \mathrm{min}\right)$; end temp.: $280^{\circ} \mathrm{C}(10 \mathrm{~min})$.

15, $\mathrm{dr}=1.7: 1$

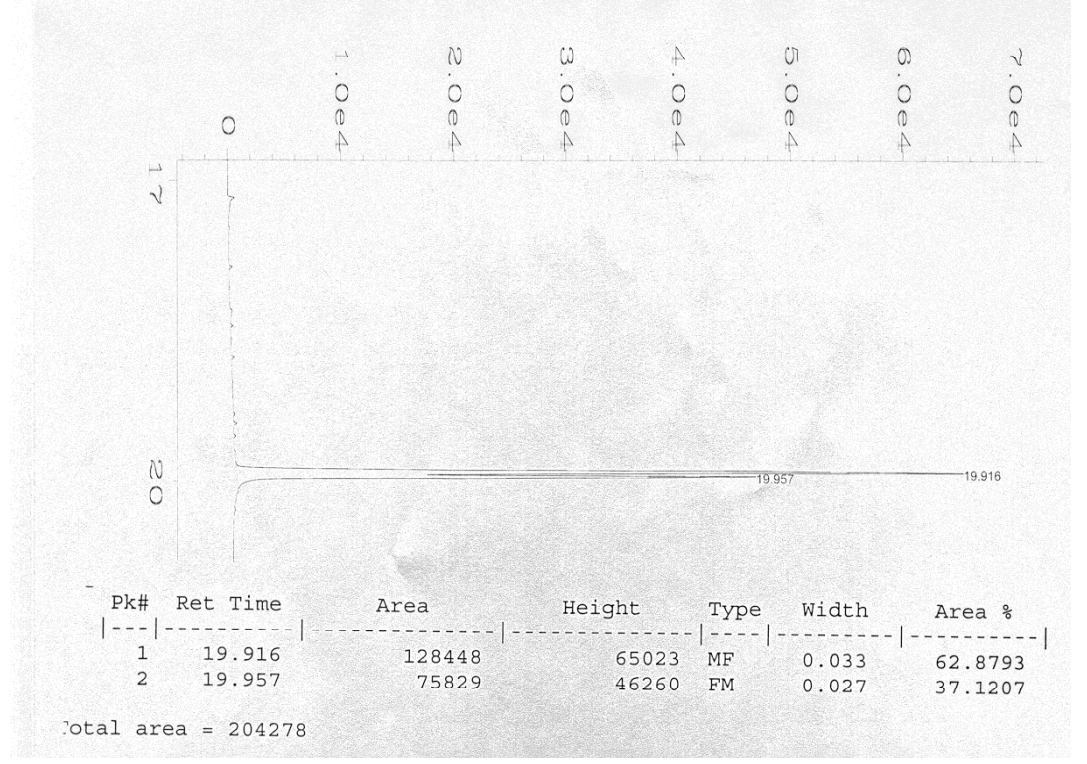

15, $\mathrm{dr}=1: 3$ 


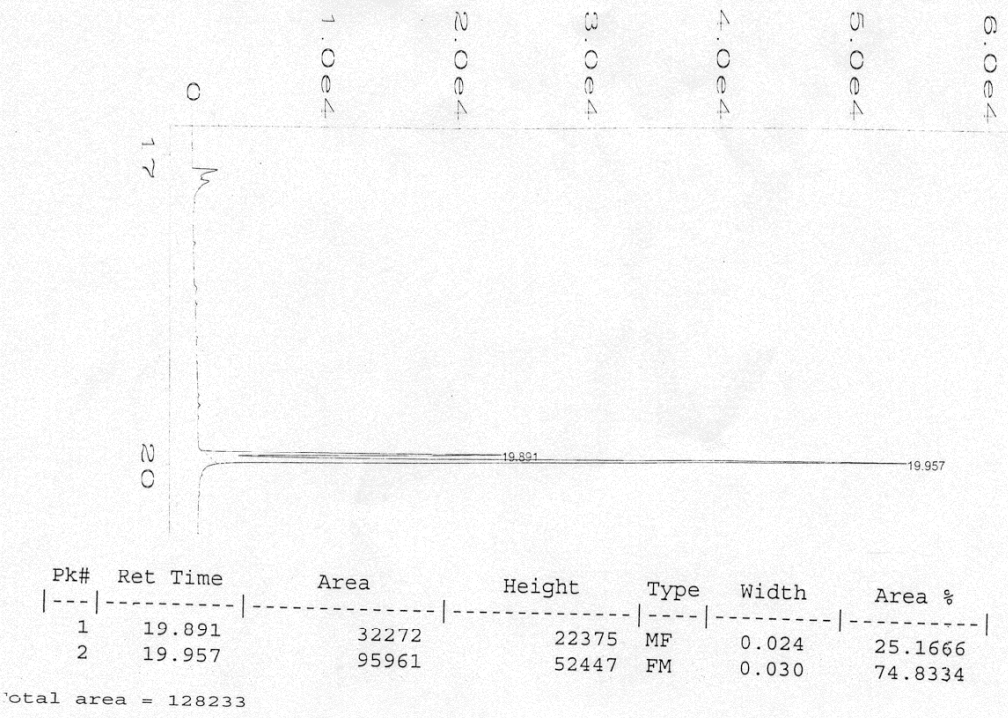

